\title{
War and order in the regional system
}

\section{The roots of war}

War has profoundly shaped the Middle East regional system. The Middle East has two of the world's most enduring conflict centres, each originating in the impact of the West on the region. The establishment of Israel at the expense of the indigenous Palestinians led to a chain of wars, each of which added new grievances and issues complicating the possibility of a resolution. In the Gulf, the struggle over oil and oil routes has been expressed in another chain of wars which can be traced back to the Western overthrow of Muhammed Mossadeq who had attempted to nationalise Iran's oil; this was a major factor in the Iranian revolution which set the stage for the first and second Gulf wars. Conflicts over Israel and oil have tended to feed on each other, as in the 1973 oil embargo triggered by the Arab-Israeli war of that year.

War has originated in domestic level dissatisfaction shaped by these struggles which, when institutionalised in rival states, is expressed in conflict at the states system level, frequently over territory. Everywhere, in a region afflicted with irredentism, domestic politics encourages nationalist outbidding. Revolution in states such as Egypt and Iran has brought leaders to power who seek to export their ideology; in mobilising new social forces, it has tended to strengthen certain states and upset power balances. Demographic, ideological or political expansionist impulses have been built into the very fabric of some states, as is arguably so of Israel (a settler state) and Iraq (an artificial state), which, between them, have launched five wars against their neighbours. Weak or authoritarian regimes have made repeated miscalculations, plunging their states 
into unplanned wars, as in 1967, or mis-planned ones, such as Iraq's misadventures. While the anarchic logic of a states system need not, in itself, reproduce a struggle for power, each war has been a watershed in the 'construction' of such a Hobbesian system in the Middle East. The security dilemma has been played out to the full, with states' fear-driven accumulation of power only increasing insecurity for their neighbours and generating periodic power imbalances that have provided occasions of war. The failure of order-building efforts to address these war-inducing factors means the Middle East has been immune to the spread of the 'zone of peace'.

\section{The emergence of a Middle East system}

\section{Built-in irredentism: origins of the Arab-Israeli conflict}

The irredentism built into the flawed states system imposed on the region after World War I was epitomised by the conflict over Palestine, perhaps the single factor which has most profoundly shaped Middle East international politics. This conflict originated in the rise of the Zionist movement whose profoundly irredentist project was to literally recreate an 'old nation' on the ruins of a newly awakening - Arab Palestinian - one. The Zionist movement believed the Jews made up a nation and were entitled to a state, logically on the territory of Biblical Israel. They convinced the British government, which calculated that a Jewish presence in Palestine would support its control over the area, to sponsor a homeland for Jews in Palestine (the Balfour Declaration) although contemporaneously Britain was (in the MacMahon-Hussein correspondence) also making a largely incompatible commitment to Arab self-determination in historic Syria (Gerner 1991: 29-30, 34-5; Knightly 1991: 11; Schulze 1999; Smith 1996: 45-6). After Britain acquired the post-World War I mandate over Palestine, Zionist settlement began in earnest. Although the Balfour Declaration specified that the Jewish homeland should not 'prejudice the rights of the existing population', the Zionist project meant two peoples claiming the same land and conflict between incoming settlers and the Palestinian community was inevitable. In 1890, Jews made up 3 per cent of the population of Palestine and 11 per cent in 1922 but by 1948 they constituted around one third. They were initially concentrated in urban enclaves but by 1948 they were able to acquire $8-10$ per cent of the land, largely through purchase 
from absentee landlords (Gerner 1991: 11, 17-18; Smith 1996: 24, 107).

Zionist emigration provoked the political arousal of the Palestinian community and engendered a distinct Palestinian identity. Palestinian resistance took the form of protests and non-co-operation with the British authorities, and in 1936-39 a major uprising. This rebellion failed due to Palestinian divisions and British imperial might, but, to appease Arab opinion, Zionist emigration was limited until World War II when the Jewish exodus from Europe began. When the British withdrew from Palestine in 1948 and the Palestinians rejected a United Nations (UN) resolution partitioning Palestine at their expense, the Zionists declared the founding of the state of Israel. The armies of Arab states intervened, ostensibly to rescue the Palestinians.

The first Arab-Israeli war is often depicted as an unequal contest in which the infant Israeli state fought off Arab attempts to strangle it in its crib. In fact, the virtual destruction of the Palestinian national movement in the British repression of the 1936 rebellion left the Palestinians nearly defenceless while the British had allowed their Zionist counterpart to arm itself during World War II - thereby sowing the seeds of the Israeli army (Gerner 1991: 44-6; Smith 1996: 115-17, 140). The well-organised and mobilised Zionist movement entered the conflict as a state-in-formation while the fragile Arab monarchies and oligarchies were too dependent on the West and too paralysed by rivalries to adopt an effective position against it. Far from being zealous for war, it was only their fear that Arab public opinion would hold them responsible for the loss of Palestine that led to their half-hearted intervention. Egypt's Prime Minister Nuqrashi told the Egyptian commander that intervention would be a mere political demonstration for public consumption. Saudi Arabia was completely unwilling to endanger its US relations by adopting the anti-Western economic sanctions called for in Arab League resolutions (Maddy-Weitzman 1993: 61-7). Jordan's King Abdullah reached an understanding with the Zionists to occupy the Arab areas in the partition plan and thereafter maintained a tacit ceasefire that permitted them to make gains at the expanse of the Egyptian army in the south and in Galilee during the second round of the war. In large part because of Abdullah's ambitions and the concern of the other Arab states to thwart them as much as to counter Israel, the Zionists were able to wage successful offensives 
against each Arab army consecutively (Sela 1998: 40). Similarly, in the truce negotiations with Israel, Egypt and Jordan eschewed the common stand that might have improved their leverage. Subsequently King Abdullah not only annexed the Palestinian territory that his army controlled (the 'West Bank') to his Kingdom in defiance of the Arab League and Palestinian claims, but was even prepared to enter a separate peace with Israel.

The first Arab-Israeli war created the conditions for further wars since the fighting was ended by a mere armistice that left the main issues unresolved. Israel had acquired much more territory than the UN partition plan allowed, indeed over three-quarters of Palestine, leaving the so-called 'West Bank' rump in the hands of Jordan and the Gaza strip under Egyptian control. Fears of being caught in the fighting, aggravated by Zionist terror, led to a massive flight of Palestinian refugees who were not allowed by a triumphant Israel to return to their homes when the fighting ended in spite of UN resolutions to that effect. This Palestinian exodus left large concentrations of them on the West Bank, significant numbers in refugee camps in Lebanon and Syria, and smaller numbers in Egypt and the Gulf. The loss of Palestine threatened Palestinians, now a stateless people, with the loss of their identity. However, the Palestinian Diaspora throughout the Middle East produced a stratum of politically active intellectuals who helped radicalise the rising middleclass nationalist movements in the various Arab countries and kept the Palestinian cause at the top of political agendas. The refugee camps became the crucible of the Palestinian resistance movement, reservoirs of disaffected youth increasingly educated under UN administration, but without normal economic opportunities who had little to lose by joining the national liberation movement which would eventually become the PLO. A minority of Palestinian villagers who remained in Israel received a second-class form of citizenship which did not prevent continual creeping confiscations of their land by the Israeli state. On the other hand, Jews from the Arab countries immigrated to Israel, fleeing Arab animosity, sometimes deliberately stirred up by Zionist agents. This allowed the construction of an undiluted Jewish identity for Israel (Gerner 1991: 50-6, 59, 62-3; Peri 1988: 44; Sela 1998: 40-1; Smith 1996: 142).

The sub-state communal conflict of Palestinian and Jew had now been transformed into an inter-state conflict between Israel and its Arab neighbours (Gerner 1991: 49). The Arab states rejected peace 
with Israel. In Arab eyes, Israel was no ordinary state but an extension of the West, a bridgehead of world Jewry rejecting assimilation into the area, and which, seeking to incorporate Jews from around the world and with access to global resources, had a limitless appetite for expansion. To head off popular pressures for a second round - at least until there might be a decline in Israel's external support the Arab League states refused to establish normal relations with Israel and imposed an economic boycott against it. The Arab League consensus was enforced against King Abdullah of Jordan who had negotiated a non-belligerency agreement which even his own political elite rejected (Sela 1998: 51) and which led to his assassination. Before long, championship of the Palestinian cause would become an indispensable nationalist credential for aspiring Arab political leaders.

For Israel, the war left unfinished business that shaped its subsequent foreign policy. It lacked secure readily defensible borders, especially with Jordan, while a portion of biblical Israel (the West Bank) remained in Arab hands. Security was foremost on the agenda of the new state because, although the military capabilities of the Arab states were modest, Israel's small geographic space, lack of strategic depth and encirclement by a hostile Arab world with ten times its population, led to a sense of permanent siege. David Ben Gurion, Israel's founding leader who shaped much elite thinking, expressed Israel's perception of the Arabs: Israel, he asserted, had been inhabited by Arab invaders for 1,300 years but once the homeless, persecuted Jews had finally achieved a small notch of territory, the Arabs sought to reduce its territory, flood it with refugees, seize Jerusalem, and ghettoise it by blockade (Brecher 1972: 552; Gerner 1991: 44).

Israel responded to Arab hostility, as Brown (1988: 134) put it, with 'both bristling aggressiveness and poignantly stated yearning for peace with its neighbours'. On the one hand, Israel sought to negotiate a peace settlement that would relieve it of Arab hostility; on the other hand, the Ben Gurionists urged the permanent application of force to extract recognition and normalisation of relations on Israel's terms - i.e. Arab acceptance of its control of most of Palestine without Israeli concessions over borders or the Palestinian refugees. Ben Gurion insisted the Arabs would only accept Israel once it was shown to be invincible; they had, moreover, to be taught the costs of challenging it through disproportionate punishment. 
Incursions by displaced Palestinians, armed or not, across Israel's new borders with Jordan and Egypt were met by massive retaliation against these countries, including the targeting of civilian populations suspected of harbouring guerrillas. Continual disputes between Israel and the Arab states over poorly demarcated borders, demilitarised zones and water rights also regularly escalated into military clashes, particularly on the Syrian-Israeli frontier. The periodic clashes with neighbouring Arab countries which Israeli policy promoted had, however, the effect of inflaming and spreading PanArab nationalism which preached the idea of a common Arab nation united against Israel and its Western backers. They contributed to the rise of more radical governments more motivated and better equipped to confront Israel, and made trusteeship of the Palestine cause a prize sought by states vying for Pan-Arab leadership (Brecher 1972: 251-90: Roberts 1990: 17-21; Smith 1996: 157-9; Walt 1987: 57).

From oligarchic multi-polarity (1945-55) to the Egypt-centric Pan-Arab system (1956-70)

In the aftermath of World War II, a rudimentary Middle East order emerged amidst pervasive irredentism. The periphery states, Turkey, Iran and Israel, more advanced in nation-building, militarily stronger, and aligned with the West, flanked a weak, fragmented Arab core just emerging from colonial control. The Arab regimes were narrow-based oligarchies or dynasties, highly penetrated by the great powers, above all by Great Britain, which retained bases and treaty relations with regimes headed by its clients, and moderated regional conflicts.

Dissatisfaction with artificial boundaries was an immediate issue. The initial source of revisionism within the Arab world was unfulfilled Hashemite ambitions: Iraq's dreams of becoming an Arab Prussia unifying the Fertile Crescent and Jordan's Greater Syria scheme. The counter-alliance of Egypt and Saudi Arabia with Syria, which was most directly threatened by the Hashemite states, the restraint put on the Hashemites by their British patron, and the limited military capabilities on all sides helped preserve the systemic status quo. In addition, the shared elitist (dynastic or oligarchic) ideology of the regimes brought them to accept the rules of a multipolar system - that no state should endanger the vital interests of its neighbours (Maddy-Weitzman 1993: Mufti 1996: 21-59; Seale 
1965: 5-99). The Arab League attempted to both institutionalise respect for the sovereignty of individual states while acknowledging shared Arab identities and facilitating a collective response to the common threat from Zionism. Its legitimacy was, however, tarnished by its failure to co-ordinate the defence of Palestine and the most it achieved was a consensus against relations with Israel.

The main underlying threat to this early order was the instability within the individual states: the weak popular loyalty to newly imposed regimes within arbitrary boundaries, gross maldistribution of wealth, still incomplete de-colonisation, and the loss of Palestine - all soon more or less de-legitimised the regimes. Their weakness meant the system could be rapidly transformed by the intersection of two forces: the political mobilisation of the Pan-Arab middle class and the rise of Egypt's Nasser who sought, with considerable success, to replace Western hegemony with an Egypt-centric PanArab order.

Nasser successfully upset the oligarchic power balance on which the existing order rested but not through military superiority. Part of Egypt's pre-eminence derived from its stature as the most stable and coherent of the Arab states, with a developed bureaucracy and, unusually, a coincidence between state borders and a relatively distinctive identity. Egypt was also the most populous Arab state, having 30 per cent of the Arab population. It had, as well, the largest GNP which gave it a limited ability to provide economic aid and supported the largest army through defence expenditures double those of any other Arab state (Noble 1991: 61-5, 74-5; Walt 1987: 53). But Egypt normally could not use its army to project power, being cut off from the Arab East by Israel and constrained by international norms. What gave Egypt hegemony was Nasser's asymmetrical ability to project trans-state ideological influence, that is, to mobilise domestic pressure on other Arab leaders by appealing to their own populations in the name of Pan-Arabism while his own regime was relatively immune to similar penetration.

Behind this asymmetry was the coincidence of several developments: Nasser's successful incorporation of popular support at home, giving his regime much greater stability than the Westerndependent oligarchies and monarchies; the emergence of middleclass nationalist movements across the region, radicalised by the Arab-Israeli conflict, the struggle with imperialism, and the traditional elites' unwillingness to share power; the advent of the 
transistor radio which allowed Radio Cairo to reach this audience; and Nasser's foreign policy victories against the West - notably the Czech arms deal, his successful stand against the Baghdad Pact, and the Western failure at Suez - which transformed him into a PanArab hero. Nasser was enabled to unleash an Arab nationalist revolutionary wave which precipitated coups and movements against pro-Western regimes across the region, culminating in the fall of Hashemite Iraq, the pillar of the pro-Western order and the formation of the UAR which briefly united Egypt with the most intensely Pan-Arab state, Syria. In time, this wave was consolidated in a series of kindred Arab nationalist regimes in Syria, Iraq, Algeria, the Yemens, and later in Sudan and Libya. This outcome was a function of an imbalance in state formation and ideological legitimacy, not in military power (Barnett 1998: 100-3, 128; Cremeans 1963; Dawisha 1976: 174-5).

Egypt's ideological hegemony positioned Nasser to lay down standards of Pan-Arab conduct that forced even the remaining Western-dependent regimes to observe common Arab nationalist norms. Indeed, Nasser arguably created an informal 'Pan-Arab regime' which, in enforcing values already pervasive in Arab political culture, constrained the unfettered exercise of state sovereignty in foreign policy. The power of one core norm, independence from imperialism, was established by the defeat of Hashemite Iraq, which had insisted on its sovereign right to protect its security through the Baghdad Pact, against Egypt's claim that all Arab states had obligations toward a Pan-Arab community whose independence could only be consolidated by shouldering its own collective defence. Egypt's victory was reflected in the widespread cancelling of Western base rights and treaties and the reluctance of conservative states to overtly align with their Western protectors as they sought to appease - bandwagon with - Egypt. The second norm, the rejection of the legitimacy of Israel and support of the Palestine cause (ideally the liberation of Palestine) did not translate into effective common action against Israel but it did enforce Israel's isolation; thus, Jordan, even when most threatened by its Arab nationalist neighbours, refrained from alliance with Israel, although covertly the kingdom benefited from an understanding that Israel would intervene if Jordan appeared in danger of absorption. Finally, lip service, at least, was given to the view that inter-Arab conflict should be settled peacefully in arenas such as the Arab League or through 
mediation and, in fact, such conflict was largely confined to lowintensity ideological subversion. The 'Pan-Arab regime' was facilitated by the shared identity of Arab elites and enforced by their fear of the internal opposition Nasser could mobilise against its violation. Nasser did not become the Bismarck of the Arab world but his Pan-Arab hegemony imposed some foreign policy coherence on it and made it much more impervious to Western influence and intervention than heretofore (Barnett 1998: 8-18; Brown 1984: 88, 162-17; Gerges, 1994: 245-51; Kerr 1971; Walt 1987: 206-12). This combination allowed establishment of a relatively autonomous regional system.

Nevertheless, the Pan-Arab 'regime' was always precarious. Disagreements over Pan-Arab norms - the extent of permissible relations with the West, the degree of militancy toward Israel - and Cairo's attempt to impose its interpretation, especially when this spilled over into a revolutionary challenge to the very legitimacy of rival states, provoked an anti-hegemonic backlash. When the 1958 revolution toppled the Hashemites in Iraq and it looked as if the conservative side would be overwhelmed, Western intervention in Lebanon and Jordan checked the domino effect and helped stabilise conservative regimes. After this, Nasser's conservative rivals were less reluctant to defy him. The consequent 'Arab Cold War' (Kerr 1971) interlocked with the competition of the two superpowers whose aid and protection to the opposing camps reinforced a regional polarisation, loosely mirroring bi-polarity. However, Nasser's unwillingness to share power even with ideological allies, manifest in the failure of the UAR, stimulated an anti-Cairo reaction among kindred Pan-Arab leaders, as well. Thus, the revolutionary camp split when Abd al-Karim Qasim, Iraq's revolutionary leader, rejected Egyptian tutelage and Nasser, in response, joined Jordan and Saudi Arabia in sending troops to protect Kuwait from Qasim's 1961 challenge to its independence. The 1963 Ba'thist coups in Iraq and Syria raised the potential of a powerful new PanArab bloc, but the Ba'thists' fear of Nasser's domination caused the failure of the unity talks with Egypt: instead the weaker Syrian and Iraqi regimes balanced against ideologically kindred Egypt and challenged Nasser's leadership of the radical camp which again pushed Nasser into detente with the conservative regimes. The ideological bi-polarity which had so put pro-Western regimes on the defensive was thus cross-cut by phases of 'revolutionary polycentrism' in 
which Nasser tacitly aligned with conservative regimes against PanArab rivals, relieving the pressure on the former. Moreover, in a classic act of realist balancing, the periphery states, Israel, Iran and Turkey aligned, albeit tacitly and intermittently, in the so-called 'periphery pact' to contain the putative radical nationalist threat from the Arab core (Barnett 1998: 129-45; Kerr 1971; Walt, 1987: 67-79, 204).

As such, from the mid-1950s through the mid-1960s the regional order combined features of the balance of power with those of a supra-state community. On the one hand, the sovereignty of the individual states and the status quo state system were preserved by anti-hegemonic balancing and, in a crisis, outside intervention. On the other hand, trans-state Pan-Arabism (amidst global bi-polarity) reduced the historic permeability of the system to outside penetration and confined inter-Arab competition to the ideological level. As a security regime, this order was, however, fundamentally unstable: in institutionalising the cleavage with the non-Arab periphery, it provided no instrument, other than a precarious power balance, for addressing the security dilemma on these fault-lines; and its ideological heterogeneity provoked the nationalist competition and, ultimately, the crisis with Israel in May 1967, in which this balance was destabilised.

\section{Two Arab-Israeli wars and the reshaping of the Middle East system}

\section{The June 1967 war}

Wars are catalysts for changes in states systems and the 1967 war, no exception, signalled the decline of Egyptian hegemony and the Egypt-centric 'Arab regime'. The 1973 war precipitated a second watershed, the beginning of the Arab-Israeli peace process. These two wars marked a transitional period toward a more multi-polar state-centric system in which sovereignty started to eclipse PanArabism.

The roots of war: Israeli geopolitical needs Israel launched the 1967 war and its motives constitute its immediate cause. There was a certain expansionist impulse literally built into the fabric of Israel's identity. Israel considers itself not an ordinary state or a Middle Eastern society but the territorial base of World Jewry, the Diaspora, 
a trans-national sense of kinship which has no exact parallel in world politics (Brecher 1972: 38). Although only about 17 per cent of Jews lived in Israel in 1966 (2.3 million out of 13.4 million), it was, in principle committed to their 'ingathering': according to the Law of Return, Diaspora Jews have an automatic right of citizenship (Gerner 1991: 59; Peri 1988: 44), and Israeli policy actively promoted Jewish emigration, often settled on land from which Palestinians were dispossessed. Absorbing a growing population in an arid land led Israel to seek greater control over regional water resources, initiating projects to divert the waters of the Jordan river in the 1960s which the Arabs took as a provocation and a bid to further emigration. The parallel pressure for more land was reinforced by dissatisfaction among many Israelis with the incomplete Judaisation of the territory of ancient Eretz Yisrael and the consequent belief, among militant nationalists, that the completion of the Zionist project required the incorporation of Judea/Samaria before 1967 the Jordanian-controlled 'West Bank' of the Jordan River. This ambition was explicit and institutionalised in the Herut party but latent throughout Israeli society (Smith 1996: 193).

It was, however, security needs that most immediately motivated Israeli decision-makers. Even though Israel had twice defeated its divided Arab neighbours, the loss of even one war could spell national extinction. Israel's frontiers were uniquely vulnerable; in particular, the Jordanian-controlled West Bank was a salient protruding into Israel from which an Arab thrust to the sea could cut Israel in two. Moreover, the potential of Arab demographic and resource superiority shaped Israeli security doctrine and military practice in a way that was likely to provoke war. Given the vulnerability of its borders, Israel could not afford to fight a war on its territory and had to take one into the enemy's territory before it could threaten the homeland. Because Israel's superiority was problematic if the Arab forces effectively combined and forced a multi-front war on it, preventing such a combination was a constant of Israeli policy and this required a proactive military stance. Additionally, because Israel, being reliant on the mobilisation of reserves, could not sustain a prolonged war without great damage to its economy, wars had to be won quickly through overwhelming force. These vulnerabilities resulted in a doctrine favouring a 'pre-emptive' (first strike) strategy that aimed at quickly smashing the enemy and, in a multifront war, allowing one opponent to be neutralised in order to cope 
with the other/s. Since collective Arab action had normally been a function of Egyptian success in uniting the Arabs and, particularly co-ordinating with Syria and Jordan, Israel considered a whole range of Egyptian-initiated actions to be a casus belli justifying a first strike, notably the concentration of Egyptian forces in the Sinai and the ascendancy of Egyptian influence over Jordan: the Israeli 1967 first strike responded to such an emerging scenario (Brecher 1972: 51, 67).

Later wars are often the continuation of earlier rounds and 1967, no exception, was a product of dissatisfaction at the outcome of the 1956 Suez War which was, itself, a continuation of the unfinished business left over from 1948. Egypt's arming of displaced Palestinians in Gaza, who launched incursions into Israel in the early 1950s, had precipitated disproportionate retaliation against Egyptian positions and sparked an arms race between Egypt and Israel, with France becoming Israel's main supplier and the Soviet Union Egypt's. In the years before 1956, there had been some dispute within the Israeli elite over whether to escalate or de-escalate this rising conflict through diplomatic conciliation. Moshe Sharrett, Foreign Minister and briefly Prime Minister, urged the latter and Ben Gurion the former; it took Sharrett's ouster from power by the Ben Gurionists to prepare the way for war while Nasser's nationalisation of the Suez Canal, facilitating Israeli collusion with Britain and France, made the international environment permissive for a first strike on Egypt (Brecher 1972: 389-92). Israel's 1956 attack, in which it occupied Egypt's Sinai peninsula, aimed to destroy Egypt's new military capabilities, force it to reopen the Strait of Tiran which it had closed to Israeli shipping after 1948, and either destabilise Nasser's Arab nationalist government or force it to concede a peace treaty in return for evacuation of the Sinai. Israel achieved the opening of the straits and a UN force on the border which ended infiltration from Gaza, but US President Dwight Eisenhower forced its withdrawal from the Sinai without any political gains and in fact, the Israeli use of force achieved the opposite of its aims. It accelerated the spread of Arab nationalism and consolidated Nasser's stature as a Pan-Arab leader carrying responsibility for the Palestinian cause, thereby locking Egypt into confrontation with Israel. Egypt was also dissatisfied by what it considered to be the rewards Israel had received for its aggression, notably the opening of the Strait of Tiran, and in the pre-war crisis of May 1967 Nasser again closed them. 
Israel's powerful Ben-Gurionists, whose ambitions for defensible borders and/or more living space had been frustrated in 1956, found in this same crisis another opportunity to realise them (Gerner 1991: 66-9; Smith 1996: 171-4; Walt 1987: 66).

Israeli elites were, nevertheless, initially divided and the decision for war was, in some ways, a product of intra-elite power rivalries. An activist camp, dominant in the military and led by disciples of Ben Gurion such as Moshe Dayan, the hero of the Suez campaign, Yigal Allon and Shimon Peres, saw the Arabs as an implacable enemy and Nasser as the new Hitler. They were convinced that Israel enjoyed the decisive military superiority to take on the enemy (Brecher 1972: 552; Smith 1996: 196). At the same time, the irredentist Herut party of Menachem Begin was growing in influence as a pressure group for expansion and also had its advocates in the military (Brecher 1972: 247; Roberts 1990: 36; Smith 1996: 192). A pragmatic tendency in Israeli elite thinking, normally a minority view in the establishment but temporarily on the ascendancy in the mid-1960s, was more prepared to seek accommodation with the Arabs and argued against military actions that could alienate Israel's supporters in the West. The cautious and pragmatic Levi Eshkol, Prime Minister in 1967, was closer to the moderate camp.

The Ben-Gurionist hawks, who had split from the ruling Mapai party, used their image as war heroes to paint the pragmatists as soft on the Arabs. Backed by the military establishment, they used the May 1967 crisis to demand key cabinet positions in a national unity government from which they would push Eshkol into a first strike. Dayan became Defence Minister while Begin also received a portfolio in this government. While Dayan and Allon were planning a war to enlarge Israel's borders, Eshkol, innocent of such strategic visions, wished to rely on American diplomacy to defuse the crisis and was averse to a pre-emptive strike. However, he succumbed to military pressure and the hawks took charge of actual military decision-making (Kimsche and Bawly 1968: 45, 57, 62, 69; Peri 1983: 244-51).

Domestic-driven Arab regional dynamics Israel's attack on its neighbours unleashed the war but it was the dynamics of PanArabism which gave Israeli hawks the opportunity to realise their ambitions; specifically Nasser's need to protect his Arab leadership against challenges from both the left and the right led him into fatal 
brinkmanship in the spring of 1967 (Barnett 1998: 153-9; Stein, 1993: 62-7).

From the mid-1960s, Egypt, as Pan-Arab leader, was under growing pressure to act against Israel's diversion of the Jordan River. The Palestinian refugees were increasingly impatient for Arab action to resolve their plight; indeed, newly founded groups such as al-Fatah launched a guerrilla struggle against Israel that they hoped would detonate a wider Arab-Israeli war. Nasser argued that the Arab world had to build up its forces, modernise and unify before it would be ready for confrontation with Israel and, with his best forces tied down in the Yemen civil war, he could hardly afford a war. But his Arab rivals, particularly Syria, used the issue to put him on the defensive (Sela 1998: 52-3, 78). The Syrian-Israeli conflict dated back to differences over the demilitarised zones established by the 1948 armistice. Israel's 'creeping annexation' of these zones (Gerner 1991: 70), Syrian shelling of the paramilitary settlements Israel implanted in them, and the resulting massive Israeli retaliation, generated a particularly radical version of Arab nationalism in Syria and was a factor in bringing the Ba'th party to power in 1963. The radical but narrow-based Ba'thist regime began championing the Palestine cause to win domestic legitimacy and outbid Nasser for Pan-Arab leadership. To contain revisionist Syria, Nasser initiated Arab summit meetings to spread responsibility for inaction among the Arab leaders. The summits agreed to counter Israel by diverting the Jordan River sources which, since these rose in Syria, would force Damascus to bear the consequences of its own militancy. However, the Syrian Ba'th used Israeli attacks on its diversion works to embarrass Nasser, criticising the UN buffer force in the Sinai (UNEF) which prevented him from deterring Israel. Saudi Arabia, at odds with Egypt over Yemen, taunted Nasser for having troops in Yemen when they were needed against Israel. Syria took advantage of this to entice Nasser into a radical Cairo-Damascus axis. While Nasser hoped this would remove Syria's incentive for nationalist outbidding, Damascus viewed it as the essential backing for its sponsorship of Palestinian guerrilla warfare against Israel. This fedayeen action was the immediate precipitant of the escalation that would lead to war (Kerr, 1971: 96-128; Sela 1998: 75-90; Walt 1987: 86-7). It also prepared the ground for bringing Jordan into the Arab coalition encircling Israel. An Israeli raid on Jordan because of guerrilla attacks sponsored by Syria had convinced King 
Hussein that Israel did not reward moderation. He responded to the Cairo propaganda attacks that were stirring up his population by goading Nasser for his inaction, helping to bring about the inflamed crisis of May 1967 in which aroused public opinion forced him to stand against Israel. Even knowing it could cost him his territory and army, domestic pressure left Hussein no choice but to align with Egypt and Syria as war approached (Stein 1993: 65-66).

From unstable strategic environment to crisis A situation of strategic instability existed in the Middle East in 1967 because the decisive military advantage lay with the offence: since weapons, particularly aircraft, were vulnerable while no country enjoyed much strategic depth, a first strike could give decisive advantage once one or more sides had acquired a significant offensive capability. Both the Soviet Union and the West (France and the US) stepped up arms deliveries in the 1960s. While Soviet deliveries to Egypt, Syria and Iraq were quantitatively greater they were mostly defensive in nature while Israel received weapons giving it an offensive capability (Smith 1996: 196). Although far from evident to the Arabs, an imbalance of power in Israeli's favour had emerged and the Israeli generals' planning for a pre-emptive war was entirely rational. However, it took a crisis to translate this predisposition into actual war.

That crisis was provoked when in May 1967 Israeli retaliations for guerrilla incursions by Syrian-backed Palestinians climaxed in an Israeli threat to attack and overthrow the Syrian regime. The Soviet Union prodded Nasser to deter Israel and, as leader of the Arab world, he felt obliged to do so. Nasser realised the power balance, with his best forces tied down in Yemen, was unfavourable and did not, therefore, want a war but he could not remain passive. He therefore requested UN withdrawal from the Sinai and sent troops into the peninsula as a deterrent and with defensive instructions which assumed an Israeli first strike. Israel abandoned plans for an attack on Syria but began a counter-mobilisation which put it in a position to launch a more general war (Gerges 1994: 213; Gerner 1991: 71; Sela 1998: 91-3; Stein 1993: 64).

Nasser could have de-escalated but he allowed himself to be pushed into further brinkmanship by the expectations raised by his own nationalist rhetoric. Seeing a chance to win another political victory and perhaps extract some concessions from Israel on the 
Palestinian issue, he reclosed the Strait of Tiran to Israeli shipping. Popular euphoria that the Arabs were finally confronting Israel swept the front-line states into a defence pact encircling Israel. In essence, the Arab-nationalist 'outbidding' in which the rival Arab states had engaged was leading them into a war none wanted. In Israel, the crisis raised the public's sense of threat to its maximum: Egyptian troop movements, the closing of the strait and the threefront Arab alliance, gave the Israeli hawks their causus belli. Once Israel began to mobilise, at economic cost, it would not long wait for diplomacy to raise the closure of the Straits. The actual military threat to Israel was moderate: Nasser had no intention of striking first and the Israeli generals were confident of victory. The real threat was political: a superpower-brokered resolution which could strengthen Nasser and further embolden the Arabs (Gerner 1991: 71-2; Smith 1996: 199). For the Israeli hawks, the crisis was less a threat than an opportunity - to smash Nasserist Egypt and the PanArab movement while Israel still had military superiority, to achieve secure borders, force the Arabs to accept Israel and, for some, such as Menachem Begin, to realise Eretz Yisrael. Pre-emption was Israel's historic strategy and the main restraint on it had always been fear of the international repercussions, but in June 1967 the international situation was unusually permissive. (Barnett, 1998: 146-59; Peri 1983: 244-51; Sela 1998: 91-3; Smith 1996: 196-202).

International permissiveness Even as expansionist pressures were peaking in Israel, the great power restraints that had long maintained relative stability on the Arab-Israeli front were breaking down. While the Tripartite Declaration had initially restrained the arms race, the French were now giving Israel sophisticated weaponry out of resentment at Nasser's backing for Algerian independence. Nasser's challenge to Western interests in the region, inescapable if he wished to retain his leadership of Arab nationalism, had earned him accumulated resentment in the West where he was increasingly perceived as a Soviet client who should be brought down (see chapter 2, p. 30).

Nasser overplayed his hand in the crisis of spring 1967 in part because he had become complacent about his ability to manipulate bi-polarity. With the Suez precedent in mind, he miscalculated that the US would restrain Israel for fear a war would inflame Arab opinion against the West or bring confrontation with the USSR. 
Nasser's defence minister, General Shams ad-Din Badran apparently misled him into believing the Soviets had promised intervention to deter Israel; but, in fact, it was Moscow that would be deterred when war broke out by fear of a confrontation with the US (Gerges 1994: 224-5). Moreover, Nasser had given the US a commitment that Egypt would not be the one to initiate war and was led to think that the US was trying to broker a negotiated settlement of the crisis that would give him a Suez-like political victory (Gerges 1994: 218-22). But unlike the Suez War in which Egypt, clearly the victim, benefited from world opinion, in 1967 Arab rhetoric allowed Israel to portray itself as the victim of aggression to world opinion, generating a permissive environment for an Israeli first strike.

Meanwhile, US President Lyndon Johnson, a Cold War ideologue and friend of Israel, initially counselled Israeli restraint. He expected Israel would win a war, but did not want to have to intervene on Israel's behalf if the outcome was less than decisive (Gerges 1994: 230). But because he was also not ready to use US forces to open the Strait of Tiran he became resigned to letting Israel do it. Once convinced that an Israeli attack on the Arab states would not draw Washington into the conflict, Johnson, according to Israeli elites such as Dayan and Peres, gave Israel a tacit green light (Kimsche and Bawly 1968: 57). Indeed, according to Abba Eban, the US actually encouraged Israel to move against Syria once it had defeated Egypt (Gerges 1994: 222-4). When the Soviets warned the US that they would intervene to stop Israel's attack on Syria in defiance of a Security Council resolution for a ceasefire, Johnson sent a counterwarning by moving the US Sixth Fleet, although he did advise Israel to stop once it had taken the Golan Heights. The Soviets' failure to prevent the defeat of their allies was a first step in the restoration of American power in the region.

Explaining the 1967 war The 1967 war was the product of a convergence of forces on several different levels. The root cause lay in a protracted conflict of sub-state ethno-nationalisms which had become institutionalised in a system of rival states: on the Israeli side, a settler state with built-in insecurity and expansionist impulses pursuing a strategy of force to impose acceptance by its neighbours, and, in the process only inflaming their resentment; on the other side a displaced Palestinian Diaspora well positioned to drag the Arab states into support for its cause. In these conditions war 
was always possible but it was the dynamics of the states system a fluid imbalance of power in Israel's favour, an unstable strategic environment and international permissiveness - which allowed the war to happen at this particular time.

The war was not, of course, inevitable and, on the contrary, resulted from leadership choices; hence it can only be fully understood by factoring in leadership rivalties, ambitions, perceptions and miscalculations. Janice Stein (1993: 56-7) differentiates between 'wars of vulnerability' in which external and domestic threats combine in such a way to make war or at least brinkmanship seem the least costly course, and sought-after 'wars of opportunity' in which elites believe a power advantage will allow them to make gains through the use of force. The 1967 Arab-Israeli war is surely a mixed case. For Israeli elites, it was an opportunity to end Israel's strategic vulnerability by acquiring more defensible borders and forcing its acceptance in the region. For the Arab leaders, the actions they took which gave Israel an excuse to go to war issued from vulnerability rooted in the regional and domestic power struggles in which firmness against Israel was essential to legitimacy; this resulted from the rise of Pan-Arab nationalism and the inter-Arab rivalry played out through dangerous 'outbidding' and brinkmanship (Barnett 1998: 159). Far from being a mere accident, this was a war waiting to happen which could only have been prevented by international and regional statesmanship, both of which were utterly lacking.

The consequences of the 1967 war The 1967 war ushered in major alterations in the Arab-Israeli balance of power and in the regional map to Israel's advantage. Israel not only decisively defeated the Arab armies but seized the Sinai peninsula and Gaza Strip from Egypt, the Golan Heights from Syria and the Palestinian populated 'West Bank' from Jordan. In upsetting the status quo, the war might have led to an Arab-Israeli peace. United Nations Security Resolution (UNSC) Resolution 242, jointly sponsored by the superpowers in the aftermath of the war, provided an internationally accepted framework for a settlement. It amounted in essence to a proposed trade of 'land for peace'; in linking the inadmissibility of the acquisition of land by conquest to a call for all states in the region to be recognised as having the right to live in peace, it affirmed that the Arab states would now have to finally accept the 
existence of Israel and Israel would have to withdraw from the occupied territories. Although Israel denied the resolution required it to withdraw from all the territories, all other states, including the US, interpreted the resolution to mean virtually complete withdrawal (Smith 1996: 211-13).

The 1967 war also unleashed a major transformation in Arab attitudes to Israel. To be sure, in the short term, the conquest of the 1967 territories further locked the Arab states into the conflict with it. The defeated Arab nationalist regimes could not yet overtly accept a directly negotiated peace settlement and wanted a UNsponsored end to belligerency and Israeli withdrawal. But they were under no illusion that they could avoid a formal peace treaty if they were to recover their lost lands. Despite some short-term inflammation of radical public sentiment, the 1967 defeat, in giving a mortal blow to Pan-Arab dreams, started the process of Arab acceptance of the permanence, if not the legitimacy, of Israel. Egypt's defeat precipitated a realist pragmatism in the hegemonic Arab state as Nasser himself began looking to mend relations with the US and to find a diplomatic solution to the Israeli occupation (Gerges 1994: 228, 236); Asad's rise in Syria marked a similar moderation of nationalism there. Radical Arab states that had challenged Israel on behalf of the Palestine cause, in disregard of the power imbalance against them, were 'socialised' the hard way into the rules of realist prudence needed to survive in a dangerous states system. King Hussein's 1970 crushing of the Palestinian fedayeen's attempt to turn Jordan into a base of operations against Israel was another watershed that started the gradual moderation of the PLO leadership: it would soon reduce its goal to the establishment of a Palestinian state in the West Bank and Gaza. To be sure, as the chance of a diplomatic settlement faded in the years after 1967, the survival of the front-line regimes would require they re-vindicate themselves against Israel: they could not rest until the occupation of their territory, touching on vital state and regime interests more directly than the Palestine cause had ever done, was rolled back. However, as the notion of the liberation of Palestine gave way to the aim of recovering the occupied territories, an irreconcilable 'existential' conflict between the two sides was gradually transformed into a limited one over territory that was much more amenable to a compromise settlement (Sela, 1998: 27-30, 97-109; Smith 1996: 235-7).

Unfortunately, if 1967 marked the beginning of the end of Arab 
nationalist revisionism, it had the opposite effect on a triumphant Israel. Although the military hegemony Israel achieved in the war gave it cause to feel more secure, the success of a military solution to its insecurity not only reduced its motivation to reach a permanent settlement with the Arab states but actually whet its irredentist appetites. Israel insisted that a peace settlement would require the Arab states to accept direct negotiations and that it was unprepared to return to the 1967 lines. It wanted to keep strategic parts of its conquests that it insisted were needed to give it 'secure borders' including the Golan Heights, control of the Jordan River Valley, and parts of the Sinai (Roberts 1990: 25-30). Additionally, the simultaneous rise of an irredentist right-wing settler movement and of the Likud party, which, beginning in 1977, started to win elections, propelled attempts to colonise and incorporate the territories even though this meant permanent repressive rule over a large Palestinian population in violation of international law (Peleg 1988: 60; Peri 1988). The settlement drive decisively obstructed the potential to trade the occupied lands for peace. In essence, the 1967 war did not result in the compromise settlement outlined in UN Resolution 242 because the power asymmetry gave the Israelis no incentives to concede it and the Arab states no capacity to extract it. As a result, 1967 set the stage for three more wars in the space of about a decade, the Egyptian-Israeli War of Attrition (1969-70), the 1973 Arab-Israeli war and the 1982 Israeli invasion of Lebanon (Gerner 1991: 72-5; Smith 1996: 201, 208-11, 228-30).

\section{The Arab states system from Arab triangle to separate peace (the 1970s)}

The Arab Triangle Another effect of the 1967 war was to transform the Arab system from the Egypt-centred Pan-Arab one to what Ajami (1977-78) called the 'Arab Triangle'. Nasser's death and replacement by Sadat overnight reduced Egypt from hegemon of the Pan-Arab order to the status of a 'normal' state. Egypt had never had the resources of a well-rounded hegemon. It never enjoyed much capacity to project military power in the Arab world and its one attempt to do so, in Yemen, ended in stalemate; Egypt's economic superiority was never enough to allow it to provide much in economic rewards and by the late 1960s, the costs of hegemony first from Yemen, then from the 1967 defeat - were impoverishing 
the country while the growing oil revenues accruing to the oil monarchies was shifting the balance of economic power to them. Cairo's hegemony had been based largely on the ideological appeal of Arabism, but this was shattered by the 1967 defeat while growing state formation made other states less permeable to ideological penetration. Sadat, having neither the will nor Pan-Arab stature to continue Nasser's Pan-Arab role, subordinated all other concerns to the recovery of the occupied Sinai. The Pan-Arab regime had lost the hegemon which had enforced and held it together.

With the decline of the Egyptian hegemon, other Arab states acquired greater freedom to pursue state interests but those interests were now shaped by the much-increased threat from Israel. Before 1967, the expectation that the great powers would restrain Israel, the greater immediate threat Arab rivals posed to each other, and the little practical possibility of liberating Palestine had deterred effective alliance-building against Israel (Walt 1987: 265-6); afterwards, a militarily preponderant and expansive Israel had to be contained while the occupied territories were potentially recoverable. This was only possible through inter-Arab co-operation and the much-reduced threat of Cairo made this co-operation less risky for the other Arab states. Thus, Israel's military preponderance sparked an effort on the Arab side to balance it through alliance formation and military build-up (Walt 1987: 117, 120-1).

Egypt was still the pivotal Arab state and the natural leader of an Arab coalition against Israel, but it had now to lead by consensus. Gradually Egypt and Syria, under new pragmatic leaders, were thrown together by their common interest in a war for recovery of the occupied territories while Saudi Arabia took advantage of their need for financial backing to moderate their policies and achieve full partnership in core Arab affairs. If no one state had enough assets to play the Arab hegemon, an axis of the largest (Egypt), the richest (Saudi Arabia), and most Pan-Arab (Syria) states could pool complementary resources and forge an Arab consensus on war and peace. This 'Arab Triangle' would, for a period, replace Egyptian hegemony as a new basis of Arab cohesion based on the greater equality, hence trust, between the main leaders, Sadat, Asad and Feisal (Ajami 1977-78; Sela 1998: 142-5, 148; Taylor 1982: 49-56).

The three leaders began exploring two tracks for the recovery of the occupied territories. Egypt and Syria continued rebuilding their 
armies with Soviet arms financed by Arab oil money, while Sadat and the Saudis tried to enlist American pressure on Israel for a diplomatic settlement. Nasser's acceptance of the Rogers Plan had laid the grounds for a settlement and Sadat made new efforts to enlist US help in reaching one. However, another Arab-Israeli war became inevitable when the US rebuffed Sadat's diplomatic initiatives: in October 1973, Egypt and Syria launched a co-ordinated attack on the Israeli-occupied territories while Saudi Arabia deployed the oil weapon to force the intervention of American diplomacy (Heikal 1975; Sheehan 1976, Smith 1996: 226-8; Walt 1987: 117-21).

The fourth Arab-Israeli war of 1973 The conduct and outcome of the 1973 war were both shaped by and reshaped the Arab-Israeli power balance. On the one hand, tactically, Egypt's fears about Israeli air superiority led it to adopt a flawed war plan aiming at the mere seizure of a strip of land on the East bank of the Suez Canal (in order to break the diplomatic stalemate); this allowed Israel to separately concentrate on its northern and southern fronts, forfeiting the advantage of the two-front joint Egyptian-Syrian assault. When a ceasefire was called, Israeli forces were entrenched on the West bank of the canal and the Egyptian Third Army surrounded and in bad need of American intervention to restrain Israeli violations of the ceasefire and bring about a disengagement of forces. On the other hand, overall, the war altered the strategic power imbalance that had deprived the Arabs of all leverage to negotiate an acceptable settlement with Israel. The Arab armies failed to liberate the occupied territories, but their ability to challenge Israel and inflict high costs on it and the oil embargo, in threatening vital Western interests, sufficiently upset the status quo to force American intervention on behalf of a negotiated settlement. At the same time, the relative Arab success in the war (compared to 1967) endowed the front-line states with a legitimacy windfall that made it less politically risky for them to move toward a peace settlement. Arab summits following the war, led by the 'Arab Triangle' powers, legitimised a 'comprehensive peace' with Israel in return for its full withdrawal from the occupied territories and the creation of a Palestinian state in the West Bank and Gaza. They also designated the PLO as the sole representative of the Palestinians in peace negotiations. Arguably, the war gave the Arab states increased leverage to extract the settlement they wanted if they stuck together and 
played their cards right. Israel, for its part, still had the military upper hand at the end of the war and had an interest in a partial settlement, that is, one with Egypt, if that left it free to avoid settlements on its other fronts (Sela 1998: 211-13).

A new Arab order - stillborn The 1973 war seemed to revive the defunct Pan-Arab system, albeit in new form. The war caused a massive resurgence of Arab nationalism which drove all Arab states to close ranks behind Egypt and Syria: Iraqi and Jordanian forces played crucial roles in containing Israeli counter-offensives against Syria while Morocco and Saudi Arabia sent token contingents to the front lines and Algeria and the Gulf states provided finance for Soviet arms deliveries (Sela 1998: 145). Not just the shared threat but also a shared resource, the new oil wealth from the price boom unleashed by the oil embargo generated interdependence between the Arab states. The expectation that the new wealth would be shared with the states that had fought and sacrificed for the common Arab cause was partly realised by significant transfers of wealth to the latter, the migration of excess labour to the oil producers and the transfer of remittances home. The 'Arab Cold War' was decisively buried as the conservative states used aid to moderate the radicalism of the nationalist republics; subversion and media wars gave way to inter-state diplomacy (Dessouki 1982: 319-47).

These developments seemed to lay the foundations for a new more state-centric version of Pan-Arab order organised around the Arab summit system. Summits had been initiated by Nasser in 1964 in an early acknowledgement that Egypt's hegemony could no longer be imposed and that an Arab order had to be negotiated among sovereign states. Aiming not to promote Pan-Arab action but to contain Syria's demands for it by spreading the responsibility for inaction, summits began and continued as a mechanism for reversing the radicalisation of Pan-Arab norms from inter-Arab 'outbidding' (Barnett 1998: 122; Kerr 1971; Sela 1998: 75-94). But it was only after Israel replaced Egyptian hegemony as the main threat to Arab elites that summits took on sustained momentum. Summits reaffirmed the qualified sovereignty embodied in the Arab League, pledging participants to refrain from intervention in each other's internal affairs while co-ordinating the policies of the individual states to defend the common Arab interest. In the early 1970s summits legitimised and set the conditions for a peace settlement 
with Israel while marginalising radical regimes which sought to use outbidding to derail the peace process. In the late 1970s summits tried to contain Egypt's unilateralism in negotiations with Israel. In the 1980s, they were called to mobilise all-Arab resources, above all financial aid, to counter threats on the non-Arab periphery - from Israel and Iran.

Summit agendas were pre-negotiated by the major states, their resolutions, normally reached by consensus, were reflective of the lowest common denominator and their implementation was dependent on the cohesion of the 'Arab triangle' powers. Reflective of the growing Arab fragmentation after Egypt's separate peace shattered the triangle, was the decline in the effectiveness of summits in the 1980s when they were often boycotted by key feuding states. But Saudi Arabia filled the vacuum, using financial incentives agreed at summits to preserve some cohesion or to heal splits. Thus, the Arab summit of May 1989 healed the split over Egypt's separate peace with Israel. By 1996 there had been nineteen summits and they arguably had made enough difference in inter-Arab politics to establish a system somewhere between Pan-Arab aspirations of collective action and a purely state-centric 'Westphalian' system (Sela 1998: 2-23, 341-6).

Yet, simultaneously, centrifugal forces were deepening. Consolidation of the individual states meant their increased ability to put state sovereignty over Arabism. If the 1973 war and associated oil boom fuelled inter-Arab interdependencies, at the same time relative wartime success restored some of the legitimacy of the individual states and the new oil money fostered state building. The distribution of oil revenues across the system allowed states to build large armies and bureaucracies, generate new bourgeoisies with a stake in regimes, and co-opt the middle class, which, once the constituency of Arabism, now became or aspired to be part of the new state establishments. The very durability of the states as the customary framework of political life fostered their growing acceptance, if not strong affective support for them. States became far less vulnerable to Pan-Arab penetration as the Pan-Arab movements, once so readily manipulated by Nasser against his rivals, virtually disappeared or were 'statised': thus Ba'thism became the official ideology and the Ba'th party an instrument of state co-optation in Syria and Iraq. The Sadat regime, once it opted for a separate peace with Israel, fostered an Egypt-centric reaction against Arabism, exploiting resentment of 
the failure of the 'rich' Arabs or 'ungrateful' Palestinians to fund and appreciate Egypt's long sacrifice of its economic well-being to defence of the Arab cause. Indeed, the single most important event that unhinged the new Arab order was the defection of its very centre, Egypt (Barnett 1998: 183; Noble 1991: 65-70; Sela 1998: 148-50)

The shattering of the Arab triangle: Egypt's separate peace Just as the conflict with Israel gave birth to the Arab triangle, so disagreements over the conflict's resolution destroyed it as, after the 1973 war, Egypt's Sadat proceeded step-by-step, down the road to a separate peace at the expense of his Arab partners.

Although Sadat was amenable to a separate solution from the start, it was Egypt's military vulnerability at the time of the ceasefire that actually started him down this road. Sadat embraced US mediation to reach a first disengagement agreement with Israel that rescued his position on the banks of the Suez Canal; but the price of this was the virtual abandonment of the war option as Egyptian offensive forces were rolled back from the Sinai front. Needing the US to deliver Israeli withdrawal from the Sinai and the aid to solve Egypt's economic crisis, Sadat gradually sacrificed all other options to appease Washington: he further weakened the Arabs' hand and undermined Syria by pushing for a lifting of the oil embargo before there was even a first disengagement on the Syrian front and well before any comprehensive peace was on the cards; he broke his pledge to Jordan that similar Israeli withdrawal on the West Bank would have to precede further disengagement on the Egyptian front and in 1975 agreed to Sinai II, a second disengagement that left Jordan and Syria sidelined. Sinai II, in accelerating Sadat's advance along a separate road to peace and in neutralising Israel's southern front, sharply reduced Israel's incentive to reach a comprehensive settlement (Fahmy 1983: 170-87, Heikal 1983: 72-81, 188-251; Taylor 1982: 54-81). Knowing Israel was prepared to trade the rest of the Sinai for a peace that would remove Egypt, the strongest Arab state, from the Arab-Israeli power balance, and that if he stuck with Syria and the PLO in insisting on a comprehensive settlement and a Palestinian state, that he might get nothing, Sadat entered into negotiations at Camp David for what would be a separate peace (Sadat 1978: 302-4: Smith 1996: 256). For Israel's Begin, the Sinai was a price worth paying since, as it became apparent that Sadat 
would abandon the Palestinians, he saw the chance to keep the West Bank. While ostensibly the Camp David agreement provided for Palestinian 'autonomy', the subsequent failure of this to be realised did not deter Sadat from signing a separate peace with Israel in 1979. At the second Baghdad summit, Iraq and Syria jointly forced Saudi Arabia and other wavering states to ostracise Egypt. This, in forcing Egypt into greater dependence on the US, allowed the virtual neutralisation of the core Arab state by a superpower deeply biased toward Israel (Smith 1996: 256-8).

The failure to reach a comprehensive peace showed the centrality of the balance of power to order-building. The relative Arab-Israeli power balance resulting from the 1973 war meant neither side could hope to impose its will, hence each had an incentive to seek a diplomatic solution. This chance was, however, missed, in part because US arms deliveries to Israel and Egypt's separate peace, restored Israel superiority. This not only reduced its incentive to reach a comprehensive peace but radically upset the regional power balance as well. Egypt's opting out of the Arab-Israeli power balance amounted to a form of 'buck-passing', a practice which enervates the alliance stability needed to deter powerful states. In this case, the resulting power imbalance would lead directly to the fifth Arab-Israeli war of 1982.

Sadat's move toward a separate peace had, from at least the mid1970s, profoundly damaging consequences for the Arab system. First, it generated deepened insecurity throughout the Arab world that intensified the retreat to state-centric self-help by the Arab states, notably Syria, while disillusioning the PLO that Palestinian interests could be peacefully attained. The first and most destructive symptom of these tendencies was the Lebanese civil war, unleashed by conflicts over the Palestinians in Lebanon. The Sinai II agreement sparked a showdown between a coalition of Palestinians and radical Lebanese Muslims who wanted to challenge Israel in southern Lebanon and Maronite Christians determined to eradicate this disruptive threat to Lebanese sovereignty. At the same time, Syria, left extremely vulnerable to Israeli power by the collapse of its Egyptian alliance and seeking to redress the imbalance, tried to use the Lebanese civil war to impose its leadership in the Levant, especially on Lebanon and the PLO. This precipitated a PLO-Syrian conflict that would never be wholly healed (Barnett 1998: 191-200; Sela 1998: 153-213; Smith 1996: 242-53). 
Thus, if, in the 1973 war, co-operation between the Arab states benefited all, thereafter - caught in a classic prisoner's dilemma none could trust the other not to seek individual gains unilaterally. While the Arabs as a bloc may have had the leverage to extract a comprehensive settlement if no one of them settled for less, Kissinger's step-by-step diplomacy had divided them and henceforth forced them to individually play weakened hands in negotiations with Israel. When such vital interests as recovery of territory, perhaps even political survival, were at stake, each actor fell back on the self-help typical of a states system. Even as Nasserite Egypt's hegemonic role had established Pan-Arab constraints on sovereignty, its promotion under Sadat of sovereignty over Arabism released many remaining such constraints. By the middle-1980s major Arab leaders were effectively insisting that Arabism had to take a back seat to sovereignty in foreign policy making. King Hussein argued that to make Arabism the norm required collective institutions that were lacking. Sadat's successor, Husni Mubarak, told the Arabs that the only way to limit inter-Arab conflict was tolerance of a diversity of foreign policies since each state best knew its own interests. In this way, the individual states were 'deconstructing' the Arab system (Barnett 1998: 206-7; Seale 1988: 185-213; Sela 1998: 189-213).

The consequent popular disillusionment precipitated a decline in mass Arabism in the 1980s, but identifications did not necessarily attach to the states. Rather, the negative side effects of statebuilding - notably the explosion of corruption and inequality accompanying the oil bonanza - left states with legitimacy deficits and with no convincing substitute for Arabism or Islam as legitimating ideologies. Indeed, the vacuum left by the decline of Arabism was filled by heightened identification with either smaller sub-state identities or with the larger Islamic umma, especially after the Iranian Islamic revolution endowed political Islam, an alternative supra-state ideology, with enormous new credibility. Both tendencies were manifest in the Lebanese civil war in which, over time, nationalist movements fragmented into sectarian or regional factions or were displaced by the rise of Hizbollah, a trans-national Islamic movement.

While stronger states facing less mobilised, more fragmented publics were now better positioned to pursue reason of state to the neglect of Arab norms, they nevertheless still paid a legitimacy cost 
which opened the door to Islamic opposition. There were Islamic uprisings in both Syria and Egypt at the end of the decade. Iraq was especially threatened by Iran's trans-state penetration of its large Shi'a population. Even Saudi Arabia and the Gulf states who sought legitimation through Islam were vulnerable to Islamic Iran's denunciation of their 'American Islam'. As Maridi Nahas (1985) argues, the decline of Pan-Arabism made regimes especially vulnerable to revolutionary Islam because the same ills and identities that had fuelled the rise of Pan-Arabism persisted but the disaffected now turned to Islam because many states had appropriated Arab nationalism as their legitimating ideology while blatantly violating its norms.

\section{War and revolution on the peripheries (the 1980s)}

Egypt's separate peace and Iran's revolution set the stage for two wars on the 'peripheries' of the Arab core which again reshaped the Middle East system. These events massively intensified insecurity which states sought to address not through collective institutions but through self-help: state strengthening and arms races. Even as the Arab states were better enabled to manage trans-state pressures at home, each one, by thus strengthening itself and freeing itself of Pan-Arab constraints also started to become more of a potential threat to and less of a potential ally for its neighbours. This and the collapse of the Arab triangle, leaving the Arab world centre-less, spread the security dilemma from the peripheries to the heart of the Arab system. In these conditions of fragmentation, the classic realist balance of power increasingly became the main source of order. This balance, however, proved disastrously unstable, in good part because Arab fragmentation radically weakened the Arab states in the face of the non-Arab peripheries. The coincidence of abrupt power imbalances and the rise of revisionist leaderships in Israel, Iran and Iraq led to two major wars which accelerated movement toward something more closely approximating a 'Westphalian' type multipolar states system.

\section{The emergence of Arab multi-polarity}

Within the Arab core, a multi-polar struggle for power among several contending states, pursuing reason of state yet still ambitious to exercise Pan-Arab leadership, had emerged by the 1980s. This 
was a function both of Egypt's relative decline and the rise of other Arab powers. Military capabilities were now much more equally distributed: in 1970 Egypt's military expenditure was still much higher than other Arab states but by 1979 Syria and Iraq matched it and Saudi Arabia had soared ahead. In 1965 Egypt's GNP was still almost three times Saudi Arabia's; by 1978, Saudi wealth was triple that of Egypt. Egypt's percentage of Arab GNP declined from 23.4 per cent in 1965 to 7.9 per cent in 1977 (Noble 1991: 65; Telhami 1990: 96-7). Economic decline was paralleled by the eclipse of Cairo as the Arab world's political hub, registered in a decline of the percentage of inter-Arab official visits to Cairo from 52 per cent in 1958-63 to 23 per cent in 1970-75 and completed by its isolation after the separate peace with Israel (Thompson 1981). Formerly Egyptian-dominated inter-Arab institutions were now funded by and under the increased influence of the oil monarchies. Other states also caught up with Egypt in their levels of state formation: the conservative states were now stabilised through the use of oil wealth to incorporate middle strata while Ba'thist Syria and Iraq grew organisational muscle to control their fractious societies.

But no new hegemon or concert emerged to regulate inter-Arab conflict or defend the Arab core from external threats. Iraq, in a peripheral location and long contained by hostile Turkey and Iran, was finally internally consolidated and, strengthened by oil and Soviet arms, made a bid for Arab leadership. It remained marginalised under the banner of rejectionism but when Sadat forfeited Egypt's Arab leadership and the Pahlavi gendarme of the Gulf collapsed, Saddam Hussein perceived power vacuums Iraq could fill; however he soon dissipated Iraq's potential in his war with Iran. Asad's Syria, internally stabilised and with diversified (Gulf and Soviet) resources, took advantage of Egypt's isolation and Iraq's embroilment with Iran to assert Pan-Arab leadership against Israel; but it was handicapped by the decline of Pan-Arab sentiment and, in the 1980s, the pre-occupation of Arab regimes with the Gulf conflict. Saudi Arabia hesitantly assumed inter-Arab leadership, building on the leverage it could potentially wield in the West on behalf of Arab interests as the swing producer in OPEC and by using its wealth to moderate inter-Arab conflicts: indicative of this, in the 1970s it became the focus of most inter-Arab official visits. However, its military weakness made it vulnerable and therefore extremely cautious and the decline of its oil revenues after the mid- 
1980s oil bust and its growing dependency on the US for protection from Iran checked its rise. Each Arab state was strong enough to prevent hegemony by the other, but all were too driven by particular interests to forge an axis of states able to engineer all-Arab cohesion and security (Mufti 1996: 197-252; Noble 1991: 65, 71-2; Walt 1987: 137).

Its fragmentation made the Arab world exceptionally vulnerable to the powerful revisionist impulses that were being unleashed on its peripheries. Initially, the Iranian revolution snapped the Tehran-Tel-Aviv axis against Arab nationalism and threatened to shift the power balance against Israel; but Iran's effort to export revolution to its neighbours, Iraq and the Gulf states, at a time when its own military capabilities had been decimated by revolution, precipitated the Iraqi invasion of its territory and the eight-year-long Iran-Iraq war. This immediately reshuffled the deck to Israel's advantage: Iraq's marginalisation combined with Egypt's removal from the Arab-Israeli balance, freed Israel, where a revisionist government took power in 1977, to project its power in the Arab world with little restraint: in the early 1980s, Israel attacked an Iraqi nuclear reactor, bombed PLO headquarters in Tunis and invaded Lebanon. At the same time, the feeling of vulnerability of the Arab Gulf monarchies was greatly heightened by a dual perceived threat: on the one hand, the Soviet invasion of Afghanistan, plus Soviet activity in the Horn of Africa and in Democratic Yemen; on the other hand, once Iran reversed the Iraqi invasion, its intense military pressure on Iraq, on Kuwait and on Gulf shipping (Sela 1998: 217-46).

\section{The fifth Arab-Israeli war: the Israeli invasion of Lebanon}

The roots of the Israeli invasion of Lebanon lay in the ascendancy of irredentism, always latent in Israel, at a time of regional power imbalance favouring it. Israeli irredentism grew out of the militarist Zionism of Vladimir Jabotinsky, of which the Irgun movement led by Menachem Begin was a leading element. This Israeli 'right' saw the world as a permanently hostile place for Jews and the Arab-Israeli cleavage as irreconcilable. As Israeli right-wingers saw it, in a world where the strong dominated, Israel had to use any means necessary to attain its goals, a world view that, according to Peleg (1988: 62-4), expressed a 'monumental overcompensation' for the repression of Jews in the East European Diaspora. At a time 
when the mainstream of Israeli politics had considered the 1949 armistice lines as Israel's final borders, Begin had refused to accept their legitimacy. He rejected any return of the occupied territories which he identified as ancient Judea and Samaria, part of 'Eretz Yisrael'. Historically the 'right' also laid claim to Jordan in contrast to the Labour party (Mapai) which valued good relations with the Hashemite dynasty.

The Labour party's relative failure in the 1973 war shattered its traditional dominance of Israeli politics and shifted the Israeli political spectrum toward the irredentist 'right'. In 1974, Begin's Herut party joined with militant disciples of Ben Gurion, who had split from Labour, to form the Likud party. The National Religious Party, previously more centrist, joined the irredentist camp after 1967 while several rightist splinter parties later emerged holding even more radical views, such as the Tehiya party which regarded the return of the Sinai as a Begin sell-out, the Moledet faction which advocated expulsion of the Palestinian population to Jordan and the militant settler movement, Gush Emunim, which promoted illegal settlements in the occupied West Bank. When the Likud party won the 1977 elections, a former 'terrorist' leader, Menachem Begin, became Prime Minister of Israel (Roberts 1990: 45-88)

The likelihood of a more militant foreign policy under Begin was initially checked by Sadat's trip to Jerusalem, which generated such public euphoria, and such a strategic opportunity that Begin had to respond (Peretz 1988: 32). He pursued two tracks, a more accommodationist diplomacy toward Egypt and simultaneously a highly revisionist thrust in the occupied territories. Even while accepting the 'autonomy' for the West Bank prescribed by Camp David, Begin claimed Israeli sovereignty over the area, insisting that it was Israeli land temporarily and illegally occupied by Jordan in 1948 . Settlements increased threefold and settlers tenfold while Israeli acquisition of land and control of water resources was greatly accelerated. Arab mayors were dismissed and expulsions, demolition of houses and seizure of property increased (Peretz 1988: 33-5). Begin decreed the annexation of Jerusalem in 1980 and of the Golan Heights in 1981. The 1981 elections brought an even more radically irredentist leadership to power including Begin, Defence Minister Ariel Sharon, and Foreign Minister Yitzhak Shamir. While the previous Begin government had included moderates such as Ezer Weizmann who had promoted peace with Egypt, the new 
government saw this peace as an opportunity to use military power to remake the map of the Middle East.

The 1980 Egyptian-Israeli peace treaty, far from ending the Arab-Israeli conflict, had merely displaced the battle lines to the occupied West Bank/Gaza and to Lebanon. The PLO, expelled from Jordan in 1970, had in the following decade entrenched itself in Lebanon from which it sought to carry on a desultory guerrilla war against Israel. Israeli retaliation against Lebanon was a major factor in sparking the Lebanese civil war; the consequent collapse of the Lebanese government had left a no-man's land in southern Lebanon, eliminating remaining restraints on PLO activity there, and facilitated the 1976 Syrian intervention in Lebanon which had opened up a potential new front between Syria and Israel. The emergence of a PLO 'state-within-a-state' in southern Lebanon followed by the removal of Egypt, via its separate peace, from the Arab-Israeli power balance, and the consolidation of a revisionist government in Israel, set the stage for Israel's 1982 invasion of Lebanon.

The Likud government's aim was to establish unchallenged regional hegemony by smashing the PLO and punishing Syria, the last obstacles to its incorporation of the West Bank and Golan into Greater Israel. It aimed to drive both out of Lebanon and impose a client regime there, thereby isolating and encircling Syria. Hitherto, such ambitions would have been restrained for fear of the unpredictable international consequences, but at this juncture the international system was again exceptionally permissive: specifically, the very pro-Israel Reagan administration in Washington, seeing Syria and the PLO as Soviet surrogates in a new Cold War it was waging against Moscow, gave Israel a virtual 'green light' for the invasion (Peleg 1988: 64; Schiff and Ya'ari 1984: 31-43, 71-7; Seale 1988: 373-6; Smith 1996: 267-70).

Because of the simultaneous Iran-Iraq war and Egypt's separate peace, Israel's invasion of Lebanon did not, as it would once have done, stimulate a Pan-Arab counter-coalition in defence of Syria and the Palestinians. Neither Egypt nor the Gulf Arabs, who were preoccupied with the Iranian threat, could afford to antagonise Israel's US patron and were, in any case, not unhappy to see Syria pummelled because of its alignment with Iran in the Iran-Iraq war (Sela 1998: 256-7). Militarily, Syria took a beating at the hands of Israeli forces driving into Lebanon, and although the Syrian army extracted a price from Israel and stubbornly refused, as Israel 
expected, to retreat from Lebanon, Israel pushed Syrian forces from strategic sectors of Lebanese terrain, including the nerve centre, Beirut. Moreover, it expelled the PLO from Lebanon and, in the wake of the war, an American-Israeli combinazione installed a Maronite client regime in Beirut, tried to impose a virtual peace treaty on Israeli terms and made Israeli withdrawal from Lebanon contingent on Syria's. The US and Israel believed a militarily weakened and isolated Syria had no choice but to accept the Lebanese-Israeli accord and withdraw or face continued Israeli occupation of Lebanon. Yet Syria chose to defy their overwhelming military power and in a short time brought about a remarkable turnabout in the balance of forces (Petran 1987: 295-334, 345-8; Rabinovich 1987; Schiff and Ya'ari: 1984: 286-300; Seale 1988: 366-93).

Unprecedented Soviet arms deliveries, including a sophisticated air defence network, cast a protective umbrella over Syria. Syria took advantage of Iranian backing and the growing resentment of Lebanese Muslims, especially the Shi'a, against Israeli and Maronite domination to strike an alliance with them. Buttressed by Syria, Muslim militias checked the Maronite Jumayyil government's consolidation of power over the country and the intervention of American guns and planes on its behalf could not deter them. Israel, wearied by the casualties of Lebanese occupation and aware of the risks of a renewed drive against a Soviet-backed Syrian army, chose to withdraw from Lebanon. The car-bombing of US Marine positions and the downing of American bombers flying against Syrian forces in Lebanon demonstrated to the US the costs of involvement and brought about its withdrawal, too. The weakened Maronite government was forced to annul the accord with Israel. Israel, under Syrian-backed guerrilla threat, withdrew southward, ending the immediate military threat to Syria, although an Israeli 'security zone' in the south was consolidated. Thus, through a shrewd use of proxies, steadfastness under threat and Soviet backing, Syria's Asad snatched victory from the jaws of defeat. Israel found that its environment had become far more intractable than in 1967 when military power had so successfully redrawn the regional map in its favour; in particular, Syria was far better armed, organised, and determined while Lebanon proved to be an ungovernable swamp (Seale 1988: 394-420; Smith 1996: 272-5).

The Israeli leadership, in overreaching itself, had destroyed the 
domestic consensus it needed to carry on. Israeli society was polarised and Israel suffered international condemnation for its siege of Beirut and the subsequent massacres of Palestinian civilians, while thereafter the occupation of Lebanon meant mounting military casualties for no perceivable gain (Gerner 1991: 87-8). Lebanon exposed the limits put by Israel's pluralistic political system on the conduct of foreign policy: a hawkish leadership had little trouble stirring up an irredentist population, but when the costs to Israel seemed to exceed the attainable gains, the loss of public support sharply constrained leadership options and electoral politics permitted a change in leadership and policy. The public mood shifted under Begin's feet and in the 1984 elections neither major party won enough support to form a government and a national unity coalition had to be formed to extricate Israel from Lebanon. Israel's failure in Lebanon marked the beginning of a realisation that it, no more than its Arab neighbours, could attains its ends chiefly by military force. Thereafter under the Likudist Yitzhak Shamir, Israel pursued the more modest and negative ambition of evading pressures for peace long enough to irrevocably settle and incorporate the West Bank.

The Lebanon venture was to have enduring costs for Israel. It alienated Lebanon's Shi'a community and unwittingly helped give birth to Hizbollah, an Islamic resistance movement backed by Iran which contested Israel's continued hold on its southern Lebanon 'security zone', embroiling Israel in its own version of a Vietnam quagmire until it finally unilaterally withdrew in 2000. Moreover, the 1981 defeat of the PLO in Lebanon, rather than demoralising the Palestinians, stimulated the West Bank population to take its fate in its own hands, unleashing, in Gaza and the West Bank, the 'intifada' - a sustained civil uprising between 1987 and 1992 which made Israel's continued occupation more materially and morally costly than hitherto. Ironically, at the very time when its Egyptian peace treaty had virtually neutralised the external security threat to Israel from Arab armies, its irredentist drive to incorporate the occupied territories and impose its will in Lebanon resulted in new lowintensity but on-going security threats which were now 'internalised' within the bounds of territories Israel controlled. A final consequence of the war was Syria's drive for military parity with Israel which established a 'deterrence relationship' between the two states in which the level of armaments made a war too costly 
and probably unwinnable for both (Evron 1987; Schiff and Ya'ari 1984: 306-7; Smith 1996: 293-300).

\section{The Islamic revolution and the first Gulf War}

Revolutions, in bringing revisionist leaders to power and upsetting power balances, frequently lead to war which, in turn, reshapes states (Halliday 1994: 124-46). The radical transformation in Iran's foreign policy - from a main supporter of the pro-Western Middle East status quo under the Shah to its main challenger after the revolution - seemingly demonstrates the power of domestic politics to shape international behaviour. On the other hand, the case also underlined the resilience of the state system: the limited success of Islamic Iran in exporting its revolution revealed the extent to which regional states had become more immune to trans-state ideology while power balancing against Iran imposed constraints and costs which, in time, tilted the balance of Iranian domestic forces against foreign policy revisionism.

The foreign policy roots of revolution The Iranian revolution had its roots in domestic inequality and political repression but the intimate connection between this and its position in the international system inevitably made the revolution a nationalist one with profound international repercussions. The origins of the revolution go back to the 1952 nationalisation of Iranian oil by the nationalist prime minister Muhammed Mossadeq. Mossadeq acted in the belief that foreign control kept Iran's elites in the pockets of Britain and the Anglo-Iranian oil company. The consequent boycott of Iranian oil by Western oil companies ignited an economic crisis which paved the way for the CIA-backed military coup which brought him down and restored the Pahlavi Shah to power (Cottam 1979). Thereafter, Iran had to agree to the virtual denationalisation of its oil industry in which the Americans now took a 40 per cent share (Ramazani 1986: 202). For Iranian nationalists, the US was perceived to have eclipsed Britain and Russia as the main threats to Iranian independence.

The Pahlavi Shah's whole domestic strategy and regime were shaped by a profound legitimacy deficit rooted in his restoration by foreign powers at the expense of Iran's nationalist hero. Feeling intensely threatened at home by nationalist and leftist opposition, sometimes backed by the Soviets, the Shah naturally opted to rely on the Americans to consolidate his rule. Yet, a conservative nation- 
alist and driven to prove himself to Iranians, he sought to make Iran a regional power and major player in the world political economy. This, ironically, led him to pursue policies that would undermine his own regime. His oil-fuelled development program, in its spread of education, modern employment, and the consequent growth of the middle class, and in its neglect of agriculture and consequent rapid urbanisation, greatly increased the potentially politically conscious and active population. The rapid expansion of higher education created a large student body and a much-enlarged intelligentsia susceptible to opposition ideologies. At the same time, however, lacking nationalist legitimacy, the Shah could not afford to establish effective and legitimate political institutions which could accommodate their aspirations for political participation. On the contrary, his power consolidation meant repression of both the nationalist centre - Mossadeq's National Front - and the Marxist left, the main political vehicles of the modern middle and working classes, and an increasingly authoritarian concentration of power in his own hands at the expense of parliament, largely the preserve of the landed oligarchy. To reduce his dependence on the oligarchy and win wider support, he launched a land reform program but this alienated not only the landed elite but the Shi'a religious hierarchy whose waqf lands were threatened, both social forces which would otherwise have been natural props of monarchy. The Shah's control of growing oil revenues gave him an autonomy that led him to neglect the class base of his regime, making him increasingly dependent on support in the army and bureaucracy and his main instrument of control, SAVAK, the Shah's feared secret police (Cottam 1979: 320-49; Green 1982: 146-50; Halliday 1996: 53-5).

The oil-fuelled economic boom and bust of the late 1970s created the conditions for the mobilisation of discontent among the excluded middle and lower strata. State spending and massive corruption enriched a new bourgeoisie of contractors and middlemen between the state and the external market. At the same time, however, inflation (from massive state spending) eroded fixed incomes, while capital-intensive industrialisation generated insufficient jobs to absorb urbanised job-seekers. The frustration of raised expectation combined with growing inequality, which was de-legitimised by the egalitarian norms preached by both Marxists and oppositionist Islam, stimulated revolutionary sentiment (Halliday 1996: 50-3). At the same time, the Westernisation of Iran associated with oil-based 
development antagonised those, notably the Islamic clergy, who feared the threat of 'Westoxification' to the integrity of Islamic values and culture (Menashri 1990: 3). The clergy were the natural political leaders of the urban slums and semi-urbanised masses streaming in from the villages; their mobilisation of the urban plebeian strata shifted the balance of power within the opposition from the secular nationalists to Islamic leaders (Halliday 1996: 57-63).

The Shah's insecurity meant that he needed to maximise US commitment to the stability of his regime against nationalist and leftist opposition at home and in the Gulf region. The Shah's strategy was to position his regime, in line with the Nixon Doctrine, as a bulwark against Soviet power and radicalism in the Gulf. This meant such policies as support for Iraqi Kurds against the Iraqi Ba'th and intervention against Marxist insurgency in Oman in the early 1970s. Financing the military build-up needed to play regional gendarme made the Shah a price hawk in OPEC and might have put him at odds with his American patron but the recycling of much of the new revenues into arms and capital purchases from the US placated Washington (Cottam 1979: 333-42). However, the American connection only deepened public alienation. Though Iran had become a regional power, nationalists took no pride in this status, believing that the regime was a surrogate for American Middle East interests. Many believed Ayatollah Khomeini's claim that 'the Shah has squandered the oil revenues ... on buying weapons at exorbitant prices' and that Iran's oil money had ended up in the pockets of speculators and arms dealers (Menashri 1990: 28-9). Anti-Americanism was also inflamed by the combination of Washington's support for Israel and the Shah's alliance with Israel, which trained the hated SAVAK (Cottam 1979: 333).

Gradually, a broad anti-regime coalition came to embrace the liberal nationalist followers of Mossadeq, radical leftist and 'Islamic Marxist' student groups, clergy threatened by Westernisation, bazaar merchants alienated by price controls and foreign competition, leftist unionised workers, and the urbanising masses. As opposition mounted, the role of the United States was decisive. President Carter's urging of the Shah to observe human rights spread the perception in Iran that the US would not necessarily intervene to protect him, emboldening insurgents; during the revolution itself, Carter actually discouraged the massive military repression that would have been needed to turn back the revolution (Halliday 1996: 57-67). 
The anti-regime mobilisation was directed from abroad by the charismatic leader, Ayatollah Rouallah Khomeini, who enjoyed the aura of an 'imam' (vice-regent of God) and preached an ideology of Islam mixed with nationalism and hatred of the United States. The beginning of the end for the Shah was when the killing of thousands of unarmed demonstrators in September 1978 led to strikes in the oil fields demanding an end to SAVAK and to the US presence. This caused a dramatic drop in oil production and precipitated a state revenue crisis. Massive street demonstrations that carried on for weeks paralysed the country; the lower ranks of the army refused to fire on demonstrators, military indiscipline spread and the military hierarchy gradually unravelled. None of the props of the Shah's rule - oil, the army, or his American ally - could save him from the non-violent protest of a largely unarmed population alienated by his image as a foreign puppet beholden to the West and hostile to Islam.

The revolutionary roots of foreign policy Islamic Iran epitomises the case of regimes which, arising from revolutionary movements, are initially intensely driven by revisionist ideology that impugns the legitimacy of status quo states and even the regional states system. But, as with other revolutions, Iran's followed the 'natural history' delineated by Brinton (1938): first the radicals pushed the moderates out of power as the masses were increasingly mobilised against external threats to the revolution. Then came a 'Thermidor', in which the economic costs of revolution and the requirements of war and post-war economic reconstruction tilted the balance of power back to pragmatic elements.

The primacy of radical ideology in the formation of Iran's foreign policy under Khomeini had multiple roots. Deepest was the socialisation of the generation that took power in the revolution. Many were Khomeini's students, imbued with his intense hatred of the Shah and his American backers. Many were brought up on the teachings of Ali Shariati, the ideologue of the revolution, whose fusion of anti-imperialism and populism with Islam provided the basis for a coalition between the clergy and militant lay youth. The revolutionary situation itself - that is, the ideological mobilisation of militants and the radicalisation of the population in the revolutionary struggle - raised great expectations for a transformation; since the revolution was in part a reaction against the Shah's policy 
of defending the pro-Western status quo, it dictated an absolute reversal of Iran's role. The new regime won widespread support when it withdrew Iran from CENTO, joined the non-aligned movement, broke relations with Israel and turned its embassy over to the PLO. Relations were severed with Sadat's Egypt for its peace with Israel and the asylum given to the Shah. By the end of 1980, Iran had cancelled $\$ 9$ billion worth of Western arms contracts: it had no intention of continuing the recycling of petrodollars that made local control of oil resources acceptable in the West. Instead, Iran would seek to reduce the dependency which reliance on oil dictated and pursue an inward-looking road to development which maximised self-sufficiency.

Reinforcing the 'ideologisation' of foreign policy, was its use by the new elites to legitimise the initially unstable revolutionary regime. For a revolution advocating a universalistic (not purely national) ideology such as Islam, legitimation required revolutionary success abroad. The revolutionary leaders, buoyed by the success of their revolution, expected that the Muslim masses across the region would similarly respond to their Islamic $d a^{\prime} w a$ and rid themselves of client regimes; they were, therefore, ready to embark on dangerous challenges to the regional status quo. At the same time, though, the export of the revolution was meant to overcome the revolution's dangerous isolation amidst status quo states: as Khomeini put it, 'if we remain in a closed environment we shall definitely face defeat'. The revolution actually fed off external threats and sacrifice; the threat from the US and then the sense of siege and the sacrifices, particularly of sons, in the Iran-Iraq war invested ordinary people in the revolution. And, as the revolutionaries split, rivals in the postrevolutionary power struggle had to prove their revolutionary credentials through radical stances in foreign policy - freezing out moderate voices.

Khomeini's world view and the conflict with the US Khomeini's world view was central to revolutionary Iran's foreign policy. For him, the US was a major preoccupation. As he saw it, the world was dominated by 'satanic' imperialist powers - headed by the US, the 'Great Satan', and the USSR, the 'Little Satan' (especially after the Soviet invasion of Afghanistan) - which were enemies of Islam and sought to oppress the weak (mustaza'fin) and to plunder their resources (oil). This view, growing out of Iran's modern experience 
under imperialism and the Shah, was arguably reinforced by Shi'ism's historic strong sense of being the underdog; but while Shi'ism has often been quietist Khomeini's activist version preached a duty of Muslims to struggle against imperialism whose control over the region's oil could never be challenged by quietism (Hunter 1988; Menashri 1990: 71). Iran's revolution, Khomeini declared, would be a role model for the Muslim world, showing that it was possible to stand up against 'world arrogance' (Chubin 1994: 11-16). Khomeini also sought to challenge the regimes of the region which he saw as Western clients and as illegitimate obstacles to the unity of the Islamic umma. The key to revolution was the mobilisation of the mustaza'fin against an oppressive status quo.

After the Shah was given refuge in the US, Khomeini stirred up anti-American feeling, precipitating the seizure of the US embassy in November 1979 . While this may initially have been designed to block any US effort to return the Shah to power, the demand for his extradition and the return of his wealth held abroad as a condition for release of the hostages was also meant to mobilise domestic support and to show the invincibility of Islam over the 'Great Satan'. The struggle with America also became a tool and issue in the post-revolutionary power struggle between the clerical radicals and moderates. The moderates, led by Prime Minister Bazargan, wanting to resume ties with the US although on a new equal basis, tried to arrange the hostages' release. Bazargan's attempts to normalise Iran's US relations alarmed a public fearful that any of this would 'let the US in through the back door', and allowed his enemies to sweep him from power.

The cost of the hostage crisis with the US was Iran's international isolation: general condemnation, hostile UNSC resolutions, USengineered economic sanctions and the seizure of Iranian assets. Iranian relations with the USSR were little better and Iran actually rejected a Soviet offer of protection, warning it against using Iran as a cold war battleground and condemning the Soviet presence in Afghanistan (Menashri 1990: 155-6). It was this international isolation that enabled Iraq to attack Iran and face virtually no international disapprobation. Thereafter France also became an enemy for its arms deliveries to Iraq in the war. To overcome its isolation, Iran sought alternative friends - radicals or underdogs such as Syria and North Korea - and sought to foster the rise of kindred Islamic states by exporting the revolution. 
Exporting the revolution The clerical consolidation of power positioned militant ideologues to use state resources to export the revolution: the Revolutionary Guards, the Interior Ministry and the Intelligence Ministry each sponsored rival revolutionary networks abroad. They sponsored an Islamic revolutionary council which grouped Iranian backed and financed revolutionary organisations like the Supreme Assembly of the Islamic Revolution in Iraq and the Islamic Liberation Movement of Bahrain. The Ministry of Islamic Guidance promoted cultural missions, provided preachers and publications, hosted conferences of ulama from outside Iran, and broadcast the Voice of the Iranian Revolution. Iran was also able to exploit a ready-made trans-state ideological network, the Shi'a ulama throughout the Muslim world, especially those who had been trained in Iran's holy cities. The hajj was seen as a unique opportunity to convert pilgrims from all parts of the Islamic world (Menashri 1990: 157).

The impulse to spread the revolution encouraged Iranian intervention in Arab politics. If Iran was to export the revolution to the Arab heartland of Islam and overcome the barriers which its Sunnidominated Arab-Gulf neighbours sought to erect, its Islamic dawa (call) had to be seen as universal, not specifically Shi'a. Indeed, the message of Islamic revolution had a powerful trans-state appeal, similar to Nasserism, throughout the Arab world. Responding to similar grievances - that is, Israel, regimes seen to be subservient to the West, corruption, inequality and Westernisation - it exploited domestic discontent prevalent throughout the region. Its demonstration effect stimulated imitative movements in every Middle East state, including Turkey and the Israeli occupied territories (Nahas 1985).

The attempt to export revolution to Iran's traditional Gulf neighbours was a high priority. Khomeini insisted that Islam denied the legitimacy of monarchic rule and deprecated the Gulf states for their 'American Islam'. The Iranian model of Islam, anti-American, mass mobilising, anti-monarchic, and appealing to Shi'a minorities, was especially threatening to these states owing to their own liabilities: retarded nation-building, reliance on expatriate labour, and large subservient Shi'a communities. The political demonstrations conducted by Iranian hajj pilgrims, attacking the Saudi regime's US alignment, were meant to discredit Saudi Arabia as an alternative (and conservative) centre of Islam in Sunni Muslim opinion. 
Iran's message, was, however, obstructed by the Sunni-Shi'a divide and it found its strongest reception where there were concentrations of Shi'a, not only because of Shiite connections with Iran but because they were typically deprived communities, often living in states with great oil wealth. Iran inspired and aided Shi'a Islamic movements in Bahrain, where the Shi'a were 72 per cent of citizens, Iraq (60 per cent) and Kuwait (23 per cent, plus 14 per cent of Iranian origin). Iran's encouragement of Islamic rebellion against the Soviet presence in Afghanistan found resonance among the Afghan Shi'a who it backed through the Hizb al-Wahdat militia. The export of revolution was most successful in Lebanon where the Shi'a were already mobilising in the context of civil war and where a failed state could not protect its borders from massive trans-state penetration. Iran used its Syrian alliance to jump over the 'Sunni Arab barrier', insert revolutionary guards in western Lebanon, sponsor Hizbollah, and achieve a front in the Arab-Israeli conflict (Hunter 1987; Ramazani 1986:140).

The Iran-Iraq War The Iran-Iraq War appeared to grow out of a (secular-religious) clash of ideologies but if revolutionary ideology was the sole driving force of Islamic Iran's foreign policy there might well have been no war. Ba'thist Iraq was a radical force no less than Ba'thist Syria with which Tehran had formed a close alliance against the American-Israeli combinazione in the region. Yet Iran played its full role in the cycle of provocation and counter-provocation that led to war with Iraq. The outlook of the revolutionary elite was, in the case of Iraq, seemingly shaped by inherited Sunni Arab-Persian Shi'a animosity exacerbated by Iraq's mistreatment of its religiousminded Shiites. Iran calculated that Iraq, because of its majority Shi'a population, was extremely vulnerable to Islamic revolution and began encouraging Shiite dissidence especially through the Islamic Dawa Party.

From Baghdad's point of view, interests, not ideology were decisive in its decision to launch a pre-emptive war against Iran. Shiite revolutionary Islam posed a serious subversive threat to a secular regime dominated by Sunnis. But, there were certainly less risky ways than war of containing this threat and ambition was at least as important a consideration in Baghdad's decision-making. Iraq and Iran were geopolitical rivals for dominance in the Gulf but Iraq, being smaller, less populous, more vulnerable to subversion by Iran 
and its oil export lifelines exposed, had a slimmer and less secure base of national power for this contest. However, Iran's revolutionary turmoil had temporarily enervated its military capabilities while Iraq's power potential was simultaneously on the rise as its oil production, exceeding Iran's, reaped it $\$ 31$ billion in currency reserves (Ramazani 1986: 57). Saddam Hussein believed the fall of the Shah created a power vacuum that he could fill as well as an opportunity to assume the Shah's role by offering the Gulf states protection from the Islamic revolution. He also aimed to reverse the humiliating 1975 Iranian imposition of joint control over the Shatt al-Arab with which he was personally identified. He may even have imagined he could seize and keep Iran's Arabic-speaking, oil-rich Khuzistan province. As such, a classic overlapping of threat, ambition and opportunity from an apparent power imbalance shaped Iraq's decision to go to war.

Yet Iraq was biting off more than it could chew. Saddam Hussein miscalculated that he could quickly knock Iran out of the war and impose a settlement, but the Iraqi army was unable to even seize the border oil town of Abadan and Iran's ideologically mobilised forces proved unexpectedly tenacious. Saddam hoped Iran's fragmented revolutionary regime would collapse but wartime ideological mobilisation consolidated it. Iran managed to cripple Iraqi oil exports in the Gulf and its Syrian ally shut down Iraq's trans-Syria pipeline (Ramazani 1986: 70-85). Iraq also miscalculated its ability to get Soviet arms replenishments for the Soviets were wooing Khomeini and Iraq had condemned their invasion of Afghanistan. Two years after the war started, Iraq had been expelled from Iran and had expended its currency reserves. By 1983, Iran was on the offensive in Iraqi territory with the aim of overthrowing the regime and spreading the revolution.

Iraq, on the defensive, sought to regionalise and internationalise the war while Iran, enjoying natural superiority and poor relations with most states, tried to contain it to the two parties. Iran and Iraq put competing pressures on the Gulf states but an attempted Shi'a coup in Bahrain, blamed on Iranian subversion, precipitated a Saudi initiative to promote security co-ordination against Iran, leading to the founding of the GCC. Iran was in a dilemma: pressure drove the Arab Gulf states into Iraqi arms but relaxing the pressure let them contribute more to the Iraqi war effort (Ramazani 1986: 49). At the 1982 Fez summit, most of the Arab states united behind Iraq. Iraq's 
escalation of the 'tanker war' which targeted tankers loading from Iranian ports, aimed to force a Western-imposed halt to the war. In 1984-85 Iran retaliated with attacks on Saudi and Kuwaiti tankers and stopped ships to search for Iraq-bound war material. But Iran was deterred from further widening the war by growing US involvement in the Gulf and the need to avoid dissipating its forces (Calabrese 1994: 48-51).

In the event, Iraq was saved by the backing of status quo states against a revolutionary threat. Saudi and Gulf aid poured in, alternative Saudi and Turkish routes for Iraqi oil were established, and military equipment and workers arrived from Egypt. Iran was subject to Western arms embargoes while Saddam Hussein's regime was deliberately built up by the West; Western arms dealers made lucrative deals for Iraqi oil which put Iraq deeply in debt and would be a factor in its later invasion of Kuwait. France, in particular, supplied high-tech arms while US intelligence allowed Iraq to pinpoint and counter Iranian offensive build-ups. The Soviet Union also began to supply Iraq with arms once Iraqi territory was at risk. Iran, by contrast, had to resort to the international black market and seek supplies from other 'pariah' states like North Korea and its only close ally, Syria. The war continued far longer than it might otherwise have done owing to this 'borrowed capacity' (Ramazani 1986: 84).

Iran thought the faith and motivation of its troops would overcome Iraq's superior firepower, but its army's lack of military professionalism eventually weakened its offensives which ground to a halt in the face of improved Iraqi defensive capabilities (Chubin 1994: 17). Iraq's chemical weapons were effective in its 1988 counter-offensive; the war of the cities, in which Iraqi missiles rained on Iranian cities, demoralised the population which began to desert the cities, enervating the legitimacy of a leadership that could not protect its people (Chubin 1994: 21). The economic base of Iranian war capacity was also under threat. Iran needed to expand its oil quota as well as keep up prices but in 1986 Saudi Arabia flooded the market to moderate prices and recover its falling market share; this, together with Iraqi raids, crippled Iran's economic war-making capacity (Calabrese 1994: 57-62).

As long as it appeared that the war would not disrupt oil supplies, the US and the West were content to merely contain it, arguably pleased that these two potential candidates for Gulf hegemony 
checked and enervated each other to the benefit of the fragile proWestern monarchies. However, the escalation of the war of the tankers raised alarms in the West while the US perceived an Iranian threat to close the Straits of Hormuz if its own oil exports were stopped (Chubin 1994: 80-1). The US presence in the Gulf was stepped up during the later stages of the war: Kuwaiti tankers were 'reflagged' to prevent Iranian attacks on them, in 1987 there were naval engagements between Iranian and US forces, and the West made tacit threats to blockade Iran if it did not agree to UN conditions to end the war (Chubin 1994: 42). As Iran's forces were driven out of Iraq and Iran increasingly besieged, realists in the Iranian leadership were strengthened. Iran accepted the UN resolution ending the war, with Iraq enjoying the upper hand.

The war and the revolutionary regime Iran's case shows dramatically the impact of war on domestic politics. The war was provoked by the attempted ideological export of revolution and initially had the effect of consolidating the regime. On the one hand the revolutionary elite exploited Shiite traditions of martyrdom (shehadat) to energise the public and the fighters, especially the basaj, volunteers for whom revolutionary zeal substituted for training and arms; on the other hand, Iranian victories beginning in 1982 were exploited to demonstrate the rightness of the Islamic cause. The war diverted attention from troubles at home and wartime success boosted the self-confidence of the regime and the people (Hooglund 1987b; Menashri 1990 228-30).

The Iranian leadership shared a consensus on the war, namely, that it would continue until Iraq's defeat and the fall of the Ba'th regime. But, as the costs mounted, this consensus unravelled. Popular support for the war started ebbing away; a sign of this was the decline of volunteerism and the rise of draft dodging. The Musavi government's campaign against war profiteering and its provision of rationed subsidised commodities for the poor alienated merchants while its proposals for the nationalisation of foreign trade and land reform were blocked by conservative clerics tied to bazaari interests. Militant 'transnationalists' heading the revolutionary organs wanted to continue the export of revolution, notably Interior Minister Ali Akbar Mohteshemi, who was behind Hizbollah's attempt to create an Islamic republic in Lebanon. On the other side, a more pragmatic faction, including Parliament speaker Hashemi Rafsanjani, Prime 
Minister Musavi and President Khamenai, put the Iranian state's survival interests over ideological zeal (Hooglund 1987a; Menashri 1990: 305-68; Ramazani 1986: 255). The two sides also split on the role of government-to-government relations. The transnationalists held to Khomeini's original line that, since there were no just governments in the region, Iran should aid their overthrow rather than make friends with them. Rafsanjani countered that through deliberate rejection of the legitimacy of the states system and the conventions of diplomacy, Iran had so isolated itself that Iraq was able to mobilise global and regional resources on its side. 'By the use of an inappropriate method... ', he argued, 'we created enemies for our country' and failed to actively seek allies. His self-criticism was often pointed: 'If Iran had demonstrated a little more tactfulness in its relations with Saudi Arabia and Kuwait, they would not have supported Iraq' (Menashri 1990: 389, 393).

The balance between these shifting factions was fluid and often dependent on Khomeini's stand. In 1984 Khomeini came down against the transnationalists, warning that Iran would be annihilated if it did not overcome isolation; when, in retaliation, the transnationalists exposed the regime's 'hostage for arms' negotiations with the 'Great Satan', they were curbed (Ramazani 1986: 256, 264). As war reverses, falling oil prices and mounting international pressure, especially the threat of American intervention, closed in on Iran, the internal balance shifted further toward the moderates whose leader, Rafsanjani, persuaded Khomeini to accept the UNsponsored ceasefire resolution. Khomeini consented to drink the 'poisoned chalice', as he put it, to save the revolution from internal demoralisation and external encirclement (Hooglund 1989). Thereafter, the Iranian Thermidor accelerated as Rafsanjani, in charge after Khomeini's death, subordinated ideology to post-war reconstruction, not only reviving the private sector but even seeking foreign loans and investment. Gradually, the economic selfsufficiency at which the revolution had aimed was abandoned. Each step Iran took in seeking reintegration into the world economy spilled over in the moderation of its foreign policy without which economic relations to the outside could not be repaired. An increasingly 'realist' foreign policy re-established relations with Iran's Gulf neighbours and economic links to the West. Export of revolution was replaced with a more conventional attempt to create spheres of influence in Iran's immediate neighbourhood. The imprint of 
ideology survived only in the continued hostility to Israel and the US (Ehteshami 1995; Harrop 1991).

In the end, the international system tamed the Iranian revolution: it used Iraq to wear Iran down and derail its attempts to restructure its economy; having failed to overcome its dependence on oil exports, and in dire need of resources to reconstruct a war-damaged economy, Iran's now chastened realists pushed the radicals aside and sharply moderated its foreign policy ideology in the face of these realities.

\section{The states system and the periphery wars}

The Iranian and Israeli threats on the eastern and western flanks of the Arab world, rather than uniting it, polarised it into two rival coalitions shaped by differential perceptions of the greater threat. A 'moderate' coalition, which came to include Iraq, Egypt, northern Yemen, Jordan, Saudi Arabia, and the other GCC states, combined against the Iranian threat. Owing to the Gulf states' intense fear of Iran, massive resources were diverted from the Israeli front to support Iraq's war with Iran while the need for Egyptian arms and manpower on the anti-Iranian front drove Cairo's inter-Arab rehabilitation despite its adherence to its separate peace with Israel. Moreover, the US was allowed to expand its anti-Iranian presence in the Gulf despite its bombing of Libya, complicity in the Israeli invasion of Lebanon and designation of Israel as a US strategic asset. These developments, in turn, drove Syria and Iran into a defensive counter-alliance, with Iran mobilising Lebanese Shi'a on behalf of Syria's resistance to Israel in Lebanon and Syria obstructing the isolation of Iran in the Arab world. This axis, together with a so-called 'Steadfastness Front' of radical states - Libya, Democratic Yemen, Algeria - saw Israel and the US as the greater threats and sought support in Moscow.

This inter-Arab split further 'de-constructed' Arab nationalism at both elite and popular levels while, at the same time, bringing the alternative basis of regional order, the balance of power, more fully into being. Two anti-hegemonic alliances, cutting across the ideological and Arab-non-Arab fault lines, blunted the ambitions of revisionist states on the eastern and western flanks of the Arab world. Iran's revolutionary mobilisation of its superior resource base was countered by the financial aid and arms to Iraq from its Arab and Western allies, generating a stalemate in which the two 
dominant Gulf powers wore each other down. The Iranian revolution was contained, no state succumbed to Islamic revolution and the Americans were enabled to enhance their presence and influence in the Gulf, quite the opposite of what either of the two parties to the war had intended. On the Western front, Syria, sheltered by a Soviet deterrent, used the Iranian-assisted mobilisation of Lebanese Shi'a to frustrate the American-Israeli combinazione in Lebanon. The 1980s ended with the Middle East having reached a precarious peace as the costs of war exhausted all sides in both conflict arenas. This, however, was only to be the pause before the 'desert storm'.

\section{Conclusion: order without peace?}

The search for solutions to regional conflict, for a basis on which to create a secure order, has been ongoing since the founding of the Middle East states system. There are, indeed, sources of order in the region which have managed to preserve the states system, and, to a much lesser extent, to keep the peace for limited periods. However, each of the major attempts to build regional order proved defective, in varying degrees ameliorating or containing conflict but also either failing to deal with its roots or sometimes actually exacerbating it.

\section{Order and supra-state identity: a Pan-Arab regime}

Western efforts to impose an anti-communist security order on the region stimulated an indigenous response, Egypt's attempt to forge a Pan-Arab regime that would ensure Arab collective security against Israel and autonomy of Western penetration. This regime deterred the consolidation of a system of fully differentiated states, confined interArab conflict to the ideological level and rolled back Western penetration in the interests of a more autonomous Arab world (Barnett 1993, 1995, 1998). However, the threat Nasser posed to other Arab elites precipitated anti-hegemonic balancing which obstructed his attempt to enforce the 'regime'; it also stimulated defensive state formation which, in time, made the individual Arab states more immune to ideological penetration. It may be that anti-hegemonic balancing preserved the sovereignty-based states system against the potential imposition of a more integrated Cairo-dominated Pan-Arab order but the outbidding that came with this balancing also led to the disastrous 1967 war. The consequent much-increased external threat fostered an alternative sort of Pan-Arab regime based on recognition 
of sovereignty and formally realised through consensus-generating inter-state institutions, notably the Arab summits. In these forums, peer pressures and material inducements helped settle inter-Arab conflicts and unify the Arab states against shared threats. However, the weakening of Pan-Arabism by conflicts over peace with Israel increased insecurity and encouraged states' resort to self-help. The Pan-Arab regime also offered no bridge to overcome the security dilemma on the fault lines with the Middle East's non-Arab states. But the decline of Pan-Arabism, far from making for a more stable Middle East, merely spelled the replacement of Arab ideological conflicts with much more violent and sustained military conflicts on the Arab-non-Arab periphery.

\section{Toward a Westphalian order: war and the balance of power}

The growing incidence and cost of war forced states to adapt themselves to the survival imperatives of a threat-drenched system. Thus, in 1967 the radical Arab states, Egypt and Syria, driven by suprastate ideologies to challenge the status quo in defiance of the balance of power, suffered high costs. Their leaders were chastened or replaced by realists with the autonomy and capacity to more rationally match ends and means. Two decades later revolutionary Iran was similarly brought by the costs of war to adopt less ambitious and ideological foreign policies. War and threat of war also induced the adoption of realpolitik power balancing as states built up deterrent capabilities and combined against threats from ambitious powerful states. The insecurity of an anarchic system was reconstructing the states that made it up and transforming their behaviour.

Despite the socialisation of states into the traditions of balancing, the region nevertheless proved all too vulnerable to power imbalances that provided renewed occasions for war. Power imbalances were built into it by the creation of small super-rich mini-states alongside large dissatisfied ones - an ingredient of the Iraqi invasion of Kuwait - and by the unevenness of state formation which positioned early state-builders, notably the non-Arab states, to threaten those where state formation was delayed. 'Buck-passing' frustrated the construction of stable collective deterrents against such powerful threatening states; the most extreme case was the dramatic upset in the power balance resulting from Egypt's opting out of the Arab-Israeli power balance. The security dilemma was also fully operational: as high insecurity drove states to improve their power 
position, the threat they posed to their neighbours stimulated arms races, jeopardising existing power balances. This was exaggerated by the rapid power advantages achieved by states that enjoyed exceptional oil revenues or foreign aid and hence access to massive arms deliveries from external powers. Arguably, a decade of war, including Israel's 1982 invasion of Lebanon and Iraq's two Gulf wars, was partly the product of such power imbalances. In time, such ambitious states overreached themselves, stimulated anti-hegemonic alliances, and incurred high costs which restored the balance of power. The Middle East came, therefore, to exhibit certain of the self-equilibrating features of a states system: but if this was enough to preserve the system it was not enough to keep the peace. 